\title{
Paleozoic to Cenozoic sedimentary bedrock geology and lithostratigraphy of Singapore
}

Thomas J.H. Dodd*1, Martin R. Gillespie ${ }^{1}$, A. Graham Leslie ${ }^{1}$, Timothy I. Kearsey ${ }^{1}$, Rhian S. Kendall ${ }^{2}$, Thomas P. Bide ${ }^{3}$, Marcus R. Dobbs ${ }^{3}$, Ian L. Millar ${ }^{3}$, Michael Kim Woon Lee, Kiefer Chiam ${ }^{5}$ and Michael Goay ${ }^{5}$

${ }^{1}$ British Geological Survey, Lyell Centre, Research Avenue South, Edinburgh, EH14 4AP, United Kingdom.

${ }^{2}$ British Geological Survey, Cardiff University, Main Building, Park Place, Cardiff, CF10 3AT, United Kingdom.

${ }^{3}$ British Geological Survey, Environmental Science Centre, Keyworth, Nottingham, NG12 5GG, United Kingdom.

${ }^{4}$ Neptune Court, 8 Marine Vista \#15-33, Singapore 449032.

${ }^{5}$ BCA Academy, 200 Braddell Rd, Singapore 579700

*(Corresponding author email: tdodd@,bgs.ac.uk)

\section{ABSTRACT}

A new lithostratigraphical framework for Singapore is proposed, based on the analysis of $c$. $20,000 \mathrm{~m}$ of core recovered from 121 c. $205 \mathrm{~m}$ deep boreholes and augmented with 218 field localities from across Singapore. The new framework describes a succession dating from the Carboniferous to the Quaternary. New U-Pb detrital zircon dates and fossil analysis were used to constrain the ages of key sedimentary units. The oldest known sedimentary rocks in Singapore are found to be the deformed Carboniferous (Mississippian) Sajahat Formation.

These are succeeded by the newly erected, Middle and Upper Triassic, marine to continental Jurong Group and Sentosa Group successions that accumulated in the southern part of the Semantan Basin. The Jurong Group comprises four formations: the Tuas Formation, the Pulau Ayer Chawan Formation, the Pandan Formation and the Boon Lay Formation. The Sentosa Group contains two formations: the Tanjong Rimau Formation and the Fort Siloso Formation. In Singapore, the depositional record during this time is related to late Permian to Triassic arc magmatism in the southern part of the forearc basin to the Sukhothai Arc. The 
Jurong and Sentosa groups were deformed and weakly metamorphosed during the final stages of the Late Triassic to Early Jurassic orogenic event, deformation that led to the formation of the syn-orogenic conglomerates of the Buona Vista Formation. Following this, two distinct Lower Cretaceous sedimentary successions overstepped the Jurong and Sentosa group strata, including the Kusu Formation and the Bukit Batok Formation, both deposited in the southern part of the Tembeling Basin. A series of Neogene to Quaternary formations overly the Mesozoic and Palaeozoic stratigraphy, including the Fort Canning Formation, Bedok Formation and the Kallang Group.

Keywords: Lithostratigraphy, U-Pb geochronology, Jurong Group, Sentosa Group, Singapore, Southeast Asia 


\section{Introduction}

Singapore lies beyond the southern end of Peninsular Malaysia, some 50 to $100 \mathrm{~km}$ east of the southerly continuation of the Bentong-Raub Suture Zone and along strike from both the Central and Eastern belts (Sukhothai Arc and Indochina-East Malaya in Fig. 1). The two regions share a complex geological history (Hutchison and Tan, 2009), though much of the detail has remained obscure due in large part to poor exposure. In the last decade, the Government of Singapore has addressed a need to improve national geological understanding, in part by collecting new subsurface geological datasets, and by commissioning geological investigation programs to examine the new data and re-evaluate existing data. The new data include world-class examples of arc-related magmatism and associated sedimentation, and have much to offer in terms of regional geological understanding in Southeast Asia.

A number of significant interpretations of Singapore geology - including those by Scrivenor (1924), Alexander (1950), Burton (1964), and Kobayashi and Tamura (1968) predate the first official treatise, the "Geology of the Republic of Singapore" (PWD, 1976). A revised version of this document published by the Defence Science and Technology Agency (DSTA, 2009) presented a stratigraphical framework of ten units that was largely unaltered from the previous version. Much of the original mapping was not subject to assessment by techniques such as sedimentary facies analysis (Walker, 1992), and was hampered by extensive weathering of accessible outcrop (a problem that continues today and which is further exacerbated by modern urban development). Nevertheless, the unit names used in the PWD (1976) and DSTA (2009) accounts have become established and are used by geologists and geotechnical engineers active in Singapore.

In the DSTA framework, a single 'formation', the late Triassic to early Jurassic 'Jurong Formation', encompassed much of the layered rock succession in Singapore. The Jurong 
Formation' was subdivided into seven lithological associations or 'facies', namely the Tengah, Queenstown, Ayer Chawan, St. John, Jong, Rimau and Pandan facies (DSTA, 2009; Lat et al., 2016). The stratigraphy was designed in this way as a consequence of the poor exposure, structural complexity and heterolithic character of the bedrock in outcrop and in short lengths of borehole core available at the time. Although the various units and facies were assigned relationships that could be consistent with a stratigraphical classification, they do not comprise a robust lithostratigraphical framework that is fully consistent with International Commission on Stratigraphy (ICS) guidelines (cf. Murphy and Salvador, 1999), and have not achieved formal ICS-compliant status. DSTA (2009) stated that 'none of the facies can be assumed to form continuous units ... they have no stratigraphic order' and do not robustly follow fundamental geological concepts such as the Law of Superposition (developed by Nicholas Steno in 1669). Therefore, previous stratigraphical models for Singapore are based on a conceptually unsound stratigraphical framework model; for this reason, a need to review the lithostratigraphy of Singapore using new information and a modern approach was identified (Lat et al., 2016).

In order to support subsurface development, the Singapore Building and Construction Authority (BCA) implemented a comprehensive ground investigation programme, which recovered c. 20,000 $\mathrm{m}$ of borehole core from 121 c. $205 \mathrm{~m}$ deep boreholes (Fig. 2). The wealth of new data has shown that the geology of Singapore is more complicated than previously thought. The British Geological Survey (BGS) was engaged by BCA to resolve key questions about the geology and to produce an ICS-compliant lithostratigraphical framework for Singapore. BGS has examined the borehole cores and collected new data from some 218 field localities across Singapore (Fig. 2).

This paper documents and describes a new, ICS-compliant lithostratigraphical framework for Singapore (Fig. 3). The lithostratigraphical framework was developed in conjunction with 
a new lithodemic framework for the plutonic rocks of Singapore (Gillespie et al., this issue); both were supported by a re-examination of the structural geology (Leslie et al., this issue).

\section{Geological setting}

Southeast Asia is made up of a collage of continental blocks and volcanic arc terranes that are welded together along suture zones marking the sites of destroyed Palaeo-Tethys Ocean basins (Fig. 1; cf. Hall, 2012; Sone and Metcalfe, 2008; Searle et al., 2012; Metcalfe, 2017a). The geology of the Singapore-Peninsular Malaysia region is described in terms of three approximately N-S trending tectonostratigraphic belts, the Western, Central, and Eastern belts (Metcalfe, 2013). The Bentong-Raub Suture Zone forms the collisional boundary between the Sibumasu block and the Sukhothai Arc along the length of Peninsular Malaysia. After the Sibumasu block was rifted from Gondwana in the Carboniferous to Permian, its northward movement was accommodated by subduction of Palaeo-Tethys oceanic crust beneath the Indochina-East Malaya block, leading to the development of the Sukhothai Arc from the Permian at least and into the Triassic (Hall, 2009, 2012; Metcalfe, 2011, 2013, 2017a; Sevastjanova et al., 2011, 2016).

The volcanic arc system initially began to form on the continental margin of the Indochina-East Malaya block, but separated from it as a back-arc basin system developed in the Carboniferous to Permian (Sone and Metcalfe, 2008; Oliver et al., 2014). Subsequent back-arc collapse, initiating in the Permian, led to the active volcanic arc system being finally accreted back onto the continental margin (Sone and Metcalfe, 2008; Metcalfe, 2013).

Consequently, the Permian to Triassic geology of the Central Belt is dominated by stratigraphical successions and I-type granitoid plutons that record the evolution of the Sukhothai Arc (Hutchison and Tan, 2009). Widely distributed I-Type granitoid plutons in the Central and Eastern belts of Peninsular Malaysia, and in Singapore, are also a product of this arc magmatism (Ng et al., 2015a; Searle et al., 2012). These plutons show emplacement ages 
that span both the active and late-stage arc and back-arc settings (c. $265-220 \mathrm{Ma}$, see Oliver et al., 2014; $\mathrm{Ng}$ et al., 2015a, b; Gillespie et al., this issue; Leslie et al., this issue).

The Triassic successions in the Central Belt of Peninsular Malaysia, including the Semantan Formation, were deposited in the Semantan basin depocentre, which in Singapore formed the forearc basin to the Sukhothai Arc (Hutchison and Tan, 2009). These sediments comprise a diverse range of lithologies, including carbonaceous shale, siltstone, tuff, chert, and crystalline limestone (Ahmad, 1976; Metcalfe et al., 1982). Deposition is interpreted to have occurred through turbidity currents and debris flows (Metcalfe et al., 1982; Ismail et al., 2007) which transported sediment into the basin from broadly east to west (Metcalfe et al., 1982). The tuffs and abundant volcaniclastic detritus, together with evidence of basin instability, likely reflect arc activity (Abdullah, 2009). In Singapore, the presence of 'red-bed facies', including massive to finely laminated mudstones and lenses of fine-grained sandstone, have been documented in the Upper Triassic, and are thought to be deposited in a lacustrine (Oliver and Prave, 2013) or beach environment (Vilpponen, 1988).

Following the collision of the Sibumasu and Indochina-East Malaya blocks, the Mesozoic record is somewhat limited but suggests that much of what constituted the continental core of Southeast Asia at that time (Sundaland) was emergent by the early Cretaceous (Lee et al., 2004; Hall, 2009). Lower Cretaceous sedimentary successions were accumulated in faultbounded basins, often as fluvial red-bed successions. These basins formed as dextral transcurrent movements became established across the Singapore-Peninsular Malaysia region of Sundaland perhaps associated with elements of extension in a new back-arc region relative to the evolving Sunda Arc (Hutchison and Tan, 2009). Small fault-bounded basins likely joined up to form a series of basins into which the Tembeling Formation (Koopmans, 1968) or Tembeling Group (Khoo, 1977; Hutchiston and Tan, 2009) and the Ma'Okil Formation (Loganathan, 1977) were deposited in Peninsular Malaysia. 


\section{Data, methodology, and approach}

Building a 'classical' lithostratigraphy for the layered rocks of Singapore that is solely based on lithological character and using normal stratigraphical principals (as defined in Murphy and Salvador, 1999) is extremely challenging, for the reasons described above. Consequently, units have been identified and characterised using a combination of: bulk lithological character and stratal relationships determined from logging core and outcrop; sedimentary facies analysis and the interpretation of environments of deposition; geochronological dating; micro and macro fossil analysis; and structural information. Sequence stratigraphic examination of boreholes was not attempted due to a general lack of correlative chronostratigraphic data and the degree to which the rocks have been folded and faulted.

\subsection{Borehole core logging and fieldwork}

Twenty-thousand meters of borehole core recovered between 2012 and 2017 was the principal source of the data used to constrain a new bedrock lithostratigraphy for Singapore. Boreholes are typically vertical; most reach $205 \mathrm{~m}$ below surface, and the recovered cores are $61 \mathrm{~mm}$ in diameter. The boreholes are distributed widely across Singapore (Fig. 2), with the majority that intersect sedimentary strata located in the south-western part of the mainland.

A provisional lithostratigraphical framework for Singapore was developed by examining high quality photographs of all new core and preliminary logs based on obvious lithological variations in each core. On this basis, twenty-two cores (c. 4,500 $\mathrm{m}$ in total), were selected for detailed logging. The character and dip of unit boundaries, lithology, grain size, and sedimentary structures were recorded for all beds thicker than $100 \mathrm{~mm}$. The approach to rock description and classification followed the BGS 'Rock Classification Scheme' (RCS; Gillespie and Styles, 1999; Robertson, 1999; Hallsworth and Knox, 1999, modified after Tucker, 2009), which is based on several separate schemes that are widely used 
internationally. Field sedimentological logging on islands in southern and south-western Singapore (Fig. 2) was completed at 500 to $1,000 \mathrm{~mm}$-scale, capturing information on grain size, lithology, and sedimentary structure. Fieldwork facilitated observation of the lateral variation in sedimentary facies, focussing particularly on sedimentary architectural elements. All of the cored sections and outcrop localities in sedimentary rocks have been assigned to a formation, group, or member in the new stratigraphical framework (Fig. 3; Table 1).

\subsection{Facies analysis and depositional environment}

The sedimentary logging data in a subset of ten cores (Table 2; and supplementary information) and an outcrop (on Sentosa Island; Fig. 2) has been subjected to standard techniques of facies analysis (as described by Walker, 1992), allowing a detailed interpretation of strata from grain scale to basin scale, culminating in an interpretation of the environment of deposition. These sections were chosen to undergo facies analysis as they were identified as stratotype sections for each of the formations and therefore required a higher level of understanding. These stratotypes borehole cores have been retained by BCA and are accessible upon request.

Facies analysis provides a tool for the identification of various sedimentary processes from their deposits and eventually permits an accurate interpretation of the environment of deposition. A single (litho) facies describe a process, or set of processes, by which sediments were transported and eventually deposited. Facies have been combined into facies associations and distinctive successions that define characteristic packages of sediment within the new lithostratigraphical framework. Finally, interpretation of depositional environments has taken account of the sequential association of various sedimentary processes (facies successions), the sedimentary element-scale character, and both vertical (in borehole core) and horizontal (in outcrop) relationships. The original sedimentary logs of these ten borehole cores (Table 2) are provided as electronic supplementary data. 


\subsection{U-Pb detrital zircon geochronology}

The study analysed a total of seventeen samples to determine depositional age constraints from either detrital zircons in sedimentary rocks (this study, Fig. 4) or eruptive zircons in volcaniclastic rocks (see Gillespie et al., this issue) preserved in key units of the stratigraphy in Singapore.

Zircon grains were separated using standard methods, then hand-picked and mounted in epoxy disks and polished to reveal their interiors. All zircon grains were imaged using cathodoluminescence prior to analysis to allow targeting of laser spots. U-Pb analyses for zircon grains were carried out using a multicollector $\mathrm{Nu}$ Plasma HR mass spectrometer with a New Wave 193SS solid state laser, typically using a 20-25 $\mu \mathrm{m}$ laser spot. Hafnium isotope composition of zircons was carried out using a Thermo-Electron Neptune Plus mass spectrometer, coupled to a New Wave 193 UC Excimer laser. A $50 \mu \mathrm{m}$ spot was used, targeting previously dated zircon domains. Supporting information, including detailed methodologies, data tables and interpretations is supplied as electronic supplementary data. For completeness, the age information obtained for each formation within the Jurong Group has been included in the relevant sub-sections below.

Unfortunately, $\mathrm{U}-\mathrm{Pb}$ zircon ages obtained for pyroclastic rocks occurring within all four formations of the Jurong Group are statistically indistinguishable from each other, and so do not precisely constrain the lithostratigraphical succession. Collectively, these pyroclastic rocks have a mean depositional age of $242 \pm 3 \mathrm{Ma}$, making the Jurong Group either Anisian or Ladinian in age relative to the dated tuffs in the established succession.

\subsection{Micro and macrofossil analysis}

Forty-three mudstone samples from borehole cores were processed for microfossil analysis. This technique was largely unsuccessful in the provision of discriminatory age determinations, mainly as a consequence of the style and degree of deformation affecting 
these strata that has destroyed the majority of any fossil evidence. Thirteen samples of borehole core were analysed for macrofossil content providing three positive identifications, all being Triassic in age (identified in section 4.2.4). Consequently, neither micro nor macro fossil analysis has provided any additional constraint to the stratigraphy than was previously the case. However, in some units, positive macrofossil identification has provided additional control on the environment of deposition for those strata. The supporting evidence, including images and descriptions of the identified macrofossils is supplied as electronic supplementary data.

\subsection{Structural information}

Jurong Group and Sentosa Group strata have both experienced Late Triassic-Early Jurassic orogenic ductile deformation that has resulted in a single, locally strongly-developed, tectonic cleavage (Leslie et al., this issue). Younger, overstepping Cretaceous and Quaternary age formations were deposited after this deformation, and do not therefore exhibit such a cleavage. Consequently, presence or absence of a tectonic cleavage has been a useful constraint on stratigraphical position.

\subsection{Construction of a Lithostratigraphical Classification}

The new lithostratigraphical framework for Singapore follows International Commission on Stratigraphy guidelines (cf. Murphy and Salvador, 1999). Formations have been identified as the 'fundamental units' of the stratigraphy using diagnostic lithological characteristics and a justification of their stratal relationships (Table 1), supported wherever possible by geochronological (Figs 3 and 4; Gillespie et al., this issue) and palaeontological data. Where appropriate, the formations have been aggregated into groups or, in some cases, subdivided into members when the lithological properties were deemed sufficiently different from the 
rest of the parent formation. The newly defined stratigraphy described in this study provides the first ICS-compliant lithostratigraphical model for Singapore.

\section{Lithostratigraphical Framework for Singapore}

The new lithostratigraphical framework for Singapore (Fig. 3) is described below, starting with the oldest formation. For each named lithostratigraphical unit, its stratotype, diagnostic features, justification for stratal position, estimated maximum thickness, and borehole data sources are provided in Table 1.

\subsection{Sajahat Formation - Carboniferous (Mississippian)}

The Sajahat Formation is named after Pulau Sajahat (PWD, 1976), a small island c. $1.5 \mathrm{~km}$ west of the natural coastline on west side of Pulau Tekong (Fig. 2). The formation is only known to outcrop in this eastern region of Singapore, Pulau Sajahat was considered to be the ‘type locality’ (DSTA, 2009). No significant new data has come to light in this study.

The formation comprises weakly to moderately deformed and regionally metamorphosed (up to lower greenschist facies) quartz-rich sandstone (quartz-arenite and possibly quartzwacke) and mudstone, lithologies referred to as 'quartzite' and 'argillite' respectively in DSTA (2009). The quartzites display 'Bouma-type graded bedding and cross-bedded lamination' (Oliver and Gupta, 2017). At least two tectonic fabrics are identified within the Sajahat Formation, including a low-angle, regionally penetrative foliation and a second upright spaced cleavage that cross-cuts the low angle foliation (Oliver and Gupta, 2019). Sample descriptions also report the effects of contact metamorphism (DSTA, 2009); spotted metamudstone (hornfels) from Pulau Sajahat and Tanjong Renggam on Pulau Tekong contain porphyroblasts of possible cordierite ( $c f$. Oliver and Gupta, 2017, 2019).

$\mathrm{U}-\mathrm{Pb}$ detrital zircon age information has previously been reported for the Sajahat Formation, within samples of quartzite encountered in two boreholes at Punggol. The 
samples indicate the Sajahat Formation 'was deposited at or later than $337 \pm 3 \mathrm{Ma}$ and before the intrusion of a diorite dyke into the quartzite, dated as $285 \pm 1 \mathrm{Ma}$ (Pan et al., 2018), providing a range of possible ages between the early Carboniferous through to the early Permian. Since that publication, a U-Pb zircon date of $335 \pm 1$ Ma has been obtained from a granite vein that cross-cuts the Sajahat Formation (sensu Ng and Oliver, unpublished, cited in Oliver and Gupta, 2019), suggesting the Sajahat Formation can be further constrained to the Mississippian (Carboniferous).

The age of the Sajahat Formation was not measured directly in this study, but it is agreed that the formation must be older than the $285 \mathrm{Ma}$ (Artinskian) Choa Chu Kang pluton, which has recently been dated (see Gillespie et al., this issue). Xenoliths of Sajahat Formation are enclosed within this pluton in the Punggol area of northern Singapore (Gillespie et al., this issue). Correlation with the similar 'Mersing beds' of eastern Johor (Oliver and Gupta, 2017, 2019), thought to be Carboniferous (Lee, chapter 5 in Hutchison and Tan, 2009) or perhaps even the Permian age Dohol Formation (Foo, 1983; Rajah, 1986; Hutchison and Tan, 2009), further support a Palaeozoic age.

\subsection{Jurong Group - Middle Triassic}

The Jurong Group (Fig. 3) is named after Jurong Town, Singapore. Chin (1965) first identified the Jurong Formation and Pasir Panjang Formation as two lithologically distinct successions underlying the south-west part of mainland Singapore. Burton (1973a) and Burton (1973b) combined both units as the Jurong Formation. The 'Jurong Formation' outcrops in Singapore and extensively in Johor but has not been assigned formal status in Peninsular Malaysia (Lee et al., 2004). Based on the new data acquired in Singapore, the former Jurong Formation is here assigned group status (the Jurong Group), and contains four formations. The Jurong Group underlies most of the western parts of mainland Singapore (Fig. 5). 


\subsubsection{Tuas Formation}

The formation is named after and largely encountered in the Tuas planning area and is predominantly observed in boreholes in south-westernmost Singapore (Fig. 6). It is composed of interbedded, cyclic successions of limestone and siliciclastic sediments (Fig. 7A). Limestone units are 1-20 m thick, alternating with 1-20 m thick successions of very finegrained to medium-grained sandstone and minor amounts of bioturbated siltstone. The limestone is predominantly micritic with subordinate patches of allochem-rich zones that include oncoids and peloids. Parallel laminated, well-sorted, medium-grained sandstone units form coarsening-upwards packages often displaying mud-drapes and moderate bioturbation. Other sandstone intervals display erosive bases, normal grading, and occasional trough and planar cross-bedding. The sandstone units are typically dark grey, and contain an elevated concentration of clay-grade material in the matrix, with little in the way of incorporated volcaniclastic material.

The Tuas Formation is of Anisian or Ladinian in age as determined from a sample of tuff recovered from borehole $(\mathrm{BH}) 1 \mathrm{Al}$ that gives a $\mathrm{U}-\mathrm{Pb}$ zircon age of $243 \pm 2 \mathrm{Ma}$ (Fig. 3; Gillespie et al., this issue).

\subsubsection{Pulau Ayer Chawan Formation}

The formation is named after Pulau Ayer Chawan, a natural island that was joined together with six other natural islands via land reclamation to form the largely man-made Jurong Island (Fig. 2) and is mostly encountered in south-western Singapore (Fig. 6). The unit comprises interbedded sandstone and mudstone, with subsidiary, but upwards increasing occurrences of volcanogenic rock (tuff, lapilli-tuff, and tuffite) and conglomerate (Fig. 7B). Sandstone units typically are quartz-rich, sub-angular to sub-rounded and very fine- to medium-grained but occasionally coarse-grained. They often display structureless bed bases, which pass upwards into bed tops displaying parallel lamination, asymmetrical ripple 
lamination, and normal grading. Although the majority of bed-geometries are tabular, lenticular bedding is also present within the formation. Mudstones are often dark grey in colour, parallel laminated with rare occurrences of weak bioturbation. Conglomerate units are typically structureless, dominantly composed of carbonate clasts, but also contain minor quantities of granitic and volcanic rock fragments. The effects of soft-sediment deformation on discrete, stratified intervals of sandstone and mudstone are ubiquitous throughout the formation.

The Pulau Ayer Chawan Formation is of Anisian age, as determined from a sample of tuff recovered below the Nanyang Member from BH1A9 that gives a U-Pb zircon age of $245 \pm 1$ Ma (Fig. 3; Gillespie et al., this issue).

\subsubsection{Nanyang Member (of the Pulau Ayer Chawan Formation)}

The member is named after Nanyang Technological University, the site of the only known occurrence (see inset in Fig. 6). The Nanyang Member comprises pyroclastic rocks, specifically hydroclastic (quenched) lapilli-tuff, and lapillistone (Fig. 7C). More than $80 \%$ of the clasts are formed of brownish grey to green andesitic rock with much smaller proportions of dark grey mudstone and grey limestone. The igneous clasts have distinctive polygonal shapes and are concentrically zoned due to alteration. The unit consists of meter-scale layers in which normal grading is commonly visible.

The Nanyang Member is of Anisian age as determined from a sample of hydroclastic lapillistone in $\mathrm{BH} 1 \mathrm{~B} 2$, which produced a U-Pb zircon age of $245.5 \pm 2.6 \mathrm{Ma}$ (Fig. 3; Gillespie et al., this issue).

\subsubsection{Pandan Formation}

The formation is named after Pandan Road (and the nearby Pandan Reservoir). The reservoir is the site of the first borehole to intersect a substantial section of limestone in 
Singapore (Fontaine and Lee, 1993). The formation is mainly found in southern and southwestern Singapore (Fig. 6). It comprises thickly bedded carbonate rock, with subsidiary interbedded sandstone, mudstone, and pyroclastic rock (Fig. 7D). The carbonate rock is dominantly limestone with subordinate dolomite. The limestone is micritic and recrystallised to varying degrees, but in places displays sparsely distributed allochem-rich zones consisting of broken shelly material, ooids, and pisoids. Where mudstone is present, the rock commonly has a 'nodular' character with irregular to sub-spherical bodies up to $100 \mathrm{~mm}$ scale comprising dark grey mudstone enclosed in grey limestone. Occasional beds of sandstone and mudstone interrupt carbonate deposition; these are typically dark grey, moderately- to well-sorted, and have a carbonate cement. The Pandan Formation contains several thin (10$100 \mathrm{~mm}$ ) occurrences of tuff and one much thicker unit (the Kent Ridge Member, see below).

The Pandan Formation is Anisian in age, as determined from a sample of tuff recovered from near the base of formation in $\mathrm{BH} 1 \mathrm{~A} 8$, which gives a $\mathrm{U}-\mathrm{Pb}$ zircon age of $245 \pm 1 \mathrm{Ma}$ (Fig. 3; Gillespie et al., this issue), but deposition could extend into the Ladinian. A Middle Triassic age is supported by rare examples of foraminifera Citaella cf. pusilla observed in BH1F7 that argue for an Olenekian to Anisian age.

\subsubsection{Kent Ridge Member (of the Pandan Formation)}

The member is named after Kent Ridge, located in the Queenstown area of Singapore, where the thickest occurrences have been found (Fig. 6; see Figure 1 in Gillespie et al., this issue). It comprises mainly lapilli-tuff with subordinate proportions of tuff and lapillistone (Fig. 8A). The volcaniclastic rocks are composed of an ash-grade matrix with fiamme, lithic fragments, and crystals. The fiamme are green and typically $20-50 \mathrm{~mm}$ long, but can be larger. Fiamme aspect ratios (typically $4: 1$ to $8: 1$, but locally can be up to $20: 1$ ) indicate the rock has been compacted and welded to varying degrees. Lithic clasts consist dominantly of porphyritic volcanic rock, but clasts of non-porphyritic volcanic rock and coarse-crystalline 
granitic rock can be present. The crystal component consists of roughly equal proportions of bluish-grey quartz and white to pinkish feldspar (typically up to $4 \mathrm{~mm}$ in diameter).

The Kent Ridge Member is Ladinian in age, as determined from a sample of lapilli-tuff recovered from $\mathrm{BH} 1 \mathrm{~F} 13$ that gives a $\mathrm{U}-\mathrm{Pb}$ zircon age of $240.3 \pm 1.4 \mathrm{Ma}$ and a sample of tuff from BH1B6 that gives a U-Pb zircon age of $240.4 \pm 1.1 \mathrm{Ma}$ (Fig. 3; Gillespie et al., this issue).

\subsubsection{Boon Lay Formation}

The formation is named after several locations, including Boon Lay Drive, Boon Lay Place, and Boon Lay MRT station, which are close to BH2B10 (the stratotype for the unit; Fig. 2). The formation is encountered in western and northern Singapore (Fig. 6) and is composed dominantly of sandstone with subordinate interbedded mudstone and pyroclastic rock (Fig. 8B). The sandstone units are fine- to very fine-grained, but locally can be mediumto very coarse-grained, moderate- to well-sorted, and quartz-rich. The sandstone units tend to lack a clast component, but when present it is encountered directly above scour surfaces. The dominant sedimentary structures include erosive bases and trough cross-bedding, which passes up into planar cross-bedding, and bed tops characterised by parallel lamination and asymmetrical ripple lamination. Occasionally, up to $5 \mathrm{~m}$ thick intervals of flasar-laminated sandstone are encountered within coarsening-upwards packages of sediment. The bivalves Lopha cristagalli (Linnaeus), Halobia and Mysidioptera have been positively identified within mudstone units from the formation in $\mathrm{BH} 2 \mathrm{~F} 3$. Volcaniclastic sandstone is quite common and is usually yellowish-green. Mottled texturing is often present within the siliciclastic and volcaniclastic sandstone units. Rare and thin intervals of carbonate rock can develop within the formation, typically forming as nodules in mudstone.

The Boon Lay Formation is interpreted to be of Ladinian or Asinian age, based largely on a sample of tuff recovered in $\mathrm{BH} 2 \mathrm{~B} 8$ that gives a $\mathrm{U}-\mathrm{Pb}$ zircon age of $243 \pm 1 \mathrm{Ma}$ and a sample 
of tuff from $\mathrm{BH} 2 \mathrm{~B} 10$ that gives a U-Pb zircon age of $243 \pm 2 \mathrm{Ma}$ (Fig. 3; Gillespie et al., this issue). These dates are corroborated by macrofossils encountered in $\mathrm{BH} 2 \mathrm{~F} 3$, including poorly preserved specimens of the foraminifera Citaella $c f$. pusilla, which had an age range of Olenekian to Anisian; the bi-valves Lopha and Halobia that suggest an Anisian to basal Ladinian and a Ladinian to Norian age, respectively (cf. Kobayashi and Tamura, 1984); and Mysidioptera supports a Triassic age (Newton, 1923).

\subsubsection{Clementi Member (of the Boon Lay Formation)}

The member is named after the Clementi planning and residential area which coincides with the main outcrop of the unit (Fig. 6). It comprises dominantly siliciclastic rocks, mainly interbedded mudstone, siltstone, sandstone, and tuff (Figs 8C and 9C). Mudstones and siltstones display a mottled, reddened texture, mudcracks and occasional drab-root halos. The mudstones typically lack any sedimentary structuring other than the mottled texturing. Sandstones are often not reddened and contain sedimentary structures including erosive bases, trough cross-bedding, passing up into planar cross-bedding, capped by parallel laminated and asymmetrical ripple lamination. Thin beds of reddened carbonate rock (limestone) or carbonate-rich rock are developed locally.

The Clementi Member is of Ladinian or Anisian age, as determined from a sample of tuff recovered from $\mathrm{BH} 1 \mathrm{~F} 12$ that gives a U-Pb zircon age of $243 \pm 3 \mathrm{Ma}$ (Fig. 3; Gillespie et al., this issue).

\subsubsection{Pengerang Formation}

The formation is named for its 'type area' at Pengerang, an area and small settlement at the south-eastern tip of Johor, Peninsular Malaysia (Fig. 2). The formation comprises mainly pyroclastic rocks, primarily lapilli-tuff and tuff. Embedded rock fragments are usually less than $50 \mathrm{~mm}$ in diameter suggesting that the lithology is generally lapilli-tuff. A thin section of 
Pengerang Formation rock from an unidentified location in Singapore consisted of "lithic tuff with andesitic fragments set in a groundmass of irregular feldspar laths, glass, and opaque ore" (DSTA, 2009). Similar rocks outcrop further across south-east Johor where they are named the Sedili Volcanic Formation (Rajah, 1986; Hutchison and Tan, 2009).

Published radiometric $\mathrm{U}-\mathrm{Pb}$ zircon age dating of a volcanic rock sample of $238.4 \pm 1.9 \mathrm{Ma}$ (Oliver et al., 2014), suggests the Pengerang Formation is Ladinian or Carnian in age.

\subsection{Sentosa Group - Upper Triassic}

The Sentosa Group (Fig. 3) is named after Sentosa Island (Fig. 2) in the 'Southern Islands' planning area of Singapore. The group as a whole is located offshore, but also occurs in the Southern Islands and Western Islands (Fig. 10) as well as in Labrador Park on mainland Singapore (see figure 4 in Leslie et al., this issue). The Sentosa Group comprises the Tanjong Rimau Formation and the Fort Siloso Formation; the stratotypes for both formations are wellexposed on Sentosa Island, along with the boundary-stratotype.

\subsubsection{Tanjong Rimau Formation}

The formation is named after Tanjong Rimau on the north-westernmost point of Sentosa Island (Fig. 10), which represents the stratotype section for the formation. The formation is composed of interbedded conglomerate, sandstone, and mudstone (Figs 9A, 9D and 11A). The conglomerate has a distinctive clast assemblage that includes conspicuous white vein quartz, volcanic rocks, extra-formational siliciclastic rocks, and metamorphic rocks. The sandstone is very fine-grained to very coarse-grained, typically thickly bedded and displays erosive bases, planar cross-bedding, trough cross-bedding, and normal grading. Stacked successions of up to $1 \mathrm{~m}$ thick beds of tabular, planar cross-bedded, very coarse-grained sandstone are common. Mudstone units are typically dark to light grey, thinly bedded, and sometimes display well-developed starved asymmetrical ripple-lamination. A range of 
structures observed towards the top of the formation includes sigmoidal cross-bedding; Skolithos burrows (Fig. 12A); flaser lamination (Fig. 12B); hummocky cross-stratification (Fig. 12C) and reactivation surfaces in cross-bedded sandstones that display opposing foreset dips and thin mud-drape reminiscent of herringbone cross-stratification (Fig. 12D). Layers of pyroclastic rock and carbonate rock are largely absent.

A youngest detrital zircon age of $209 \pm 2 \mathrm{Ma}$ (Oliver et al., 2014) from a sample of conglomerate in the Labrador Nature Reserve, which is along strike from Tanjong Rimau (see Figure 4 in Leslie et al., this issue), suggests the unit may be no older than Norian or Rhaetian Age. However, the youngest population of detrital zircons in two new samples of the Tanjong Rimau Formation, one from Telok Blangah Park ('AGLE_65_01' in Figure 4), and the other from Tanjong Rimau on Sentosa Island ('157a' in Figure 4) produced identical ages of $224 \pm 2 \mathrm{Ma}$ (Norian; Fig. 3), and this result may provide a more robust estimate for the maximum age of deposition.

\subsubsection{Fort Siloso Formation}

The formation is named after Fort Siloso, located at the north-west tip of Sentosa Island in southern Singapore (Fig. 10). The unit forms the bedrock beneath the fort and is well exposed in the area to the northeast on Sentosa Island; the shore section provides the stratotype for the formation. The unit comprises interbedded mudstone and sandstone (Fig. 11B). The mudstone is dark red to brown, mottled, and bioturbated, while the sandstone typically is very fine-grained, occasionally fine-grained, very well-sorted and quartz-rich. Sedimentary structures include: flaser lamination, asymmetrical ripple-lamination, parallel laminations, and rare occurrences of trough cross-bedding in the fine-grained sandstones. The sandstone units often form as discrete lenses, which display shallow bases and common internal reactivation surfaces, interpreted as inclined heterolithic stratification. Skolithos burrows are present in some locations. The formation lacks volcanic material, other than isolated 
examples of volcanoclastic palaeosol (Andisol) on Sentosa Island. Detrital zircon age data for the underlying Tanjong Rimau Formation (see above) indicate the Fort Siloso Formation must be Norian or younger.

\subsection{Buona Vista Formation - latest Triassic to ?Lower Jurassic}

The Buona Vista Formation is named after the Buona Vista residential district and the MRT station in the Queenstown planning area of Singapore. The unit is distributed across central and western Singapore (Fig. 10), tentatively associated with the occurrence of major thrust structures (Leslie et al., this issue). It comprises interbedded sandstone and conglomerate (Figs 9B and 11C). The sandstone is coarse- to very coarse-grained, pebbly, and often displays meter-scale planar cross-bedding. The conglomerate can be clastsupported or matrix-supported, and is characterised by rounded, cobble-grade clasts of diverse lithologies, which includes volcaniclastic rock, granitic rock, quartz, and extraformational sandstone and mudstone.

New geochronological results from the formation in BH1B2 produced a diverse range of zircon ages with populations between $c$. 243-300 Ma, and a maximum depositional age of $245 \pm 2 \mathrm{Ma}$ indicated by the youngest population (Fig. 4). These diverse age determinations indicate a geologically-varied source area, which supports an interpretation that the Buona Vista Formation conglomerates are syn-orogenic (Leslie et al., this issue), probably sourced from a nearby emergent thrust system. The age of the formation could therefore be contemporaneous with the timing of the final (late Triassic) stages collision of the Sibumasu block against Sukhothai Arc-Indochina-East Malaya (Oliver et al., 2014; Metcalfe, 2017a), but could be as young as Lower Jurassic (as discussed in Leslie et al., this issue). The possibility for the Buona Vista Formation extending into the Lower Jurassic is postulated on the youngest granite age determination reported from the Western Belt (Main Range Province) of Peninsular Malaysia (not including much younger, Upper Cretaceous-aged 
igneous bodies), being $198 \pm 2 \mathrm{Ma}$ (Liew and McCulloch, 1985; summarised in $\mathrm{Ng}$ et al., 2015b). This youngest granite age can be used to infer the timing of terminal orogenic docking ( $c f$. Leslie et al., this issue), before which time the Buona Vista Formation needed to have formed.

\subsection{Kusu Formation and Bukit Batok Formation - Lower Cretaceous}

The Lower Cretaceous stratigraphy of Singapore comprises two formations: the Kusu Formation and the Bukit Batok Formation (Fig. 3). Both formations lack any sign of the effects of brittle-ductile deformation associated with the Late Triassic-Early Jurassic orogenic event (i.e. no evidence of a penetrative tectonic cleavage), and they must therefore overstep the older penetratively deformed Triassic Jurong and Sentosa group strata.

\subsubsection{Kusu Formation}

The formation is named after Kusu Island (Fig. 2) and its known distribution is mainly through south-eastern and eastern Singapore (Fig. 10). On Kusu Island, the formation comprises sandstone and subordinate conglomerate, dipping $30^{\circ}$ towards the southeast. The sandstone is white, grey or reddish-brown, quartz-rich, contains scattered floating pebble clasts of metamorphic rock and is massive to thickly bedded (beds $0.3-1 \mathrm{~m}$ thick), in planar units up to $1 \mathrm{~m}$ thick, some with low-angle cross-bedding. The lower formation boundary is represented by an unconformity that separates the Kusu Formation from all older (deformed) units (Fig. 12E). This angular unconformity is exposed in Telok Blangah Park (Fig. 2) where the older Sentosa Group strata (Tanjong Rimau Formation) beneath the unconformity surface $\operatorname{dip} c .40^{\circ}$ to the south-west, strata above the plane of unconformity dip consistently southeast at c. $20^{\circ}$. Sentosa Group strata (the Tanjong Rimau Formation) on the north-western shore of Kusu Island (Fig. 2) dip steeply to the south-west and are cleaved. An alternative interpretation of this particular outcrop is presented in Oliver and Gupta (2019), whereby 
these geometries represent 'a large intra-formational fluvial channel within the Jurong Formation' (i.e. within the Tanjong Rimau Formation).

The youngest population of detrital zircons from a sample in the lower-most beds of the Kusu Formation at Telok Blangah Park (Fig. 3; AGLE_65_02 in Figure 4) indicates a maximum age for deposition of $225 \pm 2 \mathrm{Ma}$. However, a sample of Kusu Formation sandstone from Kusu Island ( $\mathrm{Ng}$ and Oliver, unpublished data, cited in Oliver and Gupta, 2019) produced a youngest detrital zircon age of $156 \pm 1 \mathrm{Ma}$ (Kimmeridgian), and a sample from sandstone boulders in the 'Fort Canning Boulder Bed' — which were probably sourced from weathered Kusu Formation bedrock (Oliver and Gupta, 2019) — provided a youngest detrital zircon age of $145 \pm 1 \mathrm{Ma}$ (Tithonian or Berriasian; $\mathrm{Ng}$ and Oliver, unpublished data, cited in Oliver and Gupta, 2019). These dates suggest that the Kusu Formation was deposited during or after the uppermost Jurassic (Tithonian), or probably more likely in the Lower Cretaceous (Berriasian).

\subsubsection{Bukit Batok Formation}

The formation is named after the Bukit Batok planning area in west-central Singapore and its known distributions are restricted to small areas in central to western Singapore (Fig. 10; see inset). It comprises interbedded sandstone and mudstone (Figs 9A, 9C and 11D); the sandstone typically is moderately- to well-sorted and very fine- to very coarse-grained. The organic-rich mudstone is dark grey to black and typically displays either a faint parallel lamination or mottling. Isolated erosive-based units are developed locally, characterised by immature, very poorly sorted, fine- to very coarse-grained, angular, quartz-rich sandstone.

The youngest population of detrital zircon grains in four samples from the Bukit Batok Formation (Fig. 4) indicates a maximum age for deposition of $123 \pm 1 \mathrm{Ma}$ (BH2B4(top); Fig. 3). 


\subsection{Fort Canning Formation, Bedok Formation and Kallang Group - Neogene to Quaternary}

A number of Neogene to mid-Pleistocene stratigraphical units (Lat et al., 2016) have been identified that overlie the Mesozoic stratigraphy of Singapore, namely the Fort Canning Formation and the Bedok Formation (Fig. 3). These units are overlain by the late Pleistocene to Holocene Kallang Group that represent the youngest strata in Singapore.

\subsubsection{Fort Canning Formation}

The Fort Canning Formation is named after Fort Canning Park in the Central Area planning area and occurs exclusively in the Central Business District area of downtown Singapore. There currently are no known archived core materials, and no formal type area or type section exists for the Fort Canning Formation; this formation was not examined as part of this study.

From the literature, the formation consists entirely of boulders of fresh sandstone or quartzite set in a hard matrix of sandy clayey silt or sandy silty clay (Shirlaw et al., 1990; 2003). Boulders up to $9 \mathrm{~m}$ in diameter (e.g. Nowson, 1954) and over $200 \mathrm{~m}^{3}$ have been reported (Pitts, 1984; Shirlaw et al., 1990, 2003), but they are commonly significantly smaller. The matrix is unstratified, consisting mainly of quartz and kaolin (Wong et al., 1996), and can enclose small, angular rock fragments between the larger boulders. The matrix is characteristically mottled in deep red, red and white, or red, yellow and white, but can be purple where weathered (Shirlaw et al., 2003).

The formation is placed within the 'Cretaceous to Neogene' in Lat et al. (2016), although the basis for this age determination is not indicated and no new geochronological information was produced as part of this study. It is possible the formation was deposited between the Neogene and the Quaternary; more work is required to fully understand the age relationships in this part of the stratigraphy. 


\subsubsection{Bedok Formation}

The formation is named after the Bedok planning area in south-east Singapore. This new name (sensu Lat et al., 2016) replaces several older names, including High Level Alluvium (Scrivenor, 1924), Older Alluvium (Alexander, 1950; Burton, 1964), and Old Alluvium (introduced by Walker [1956] in the Kinta Valley of Western Peninsular Malaysia and extended to the Johor-Singapore area by Stauffer, 1973; Gupta et al., 1987). It comprises an extensive sheet of weakly consolidated to unconsolidated gravel, sand, silt, and clay (Gupta et al., 1987; DSTA, 2009; Lat et al., 2016), largely encountered in eastern and northern Singapore (Fig. 10). The gravel beds, which typically lie on scoured surfaces, are clast supported and consist largely of sub-angular to sub-rounded pebbles with a matrix of coarse sand. Gravel beds typically are overlain by coarse sand with scattered granules and small pebbles. These mostly lack structure but in some cases show normal grading. Beds of wellsorted, pebbly, silty and clayey, coarse to medium sand locally contain planar or trough cross-bedding. Pebbles consist mainly of quartz, but rhyolite, chert and mudstone also occur (DSTA, 2009).

The formation is placed within the 'Neogene to early mid-Pleistocene' in Lat et al. (2016), although the basis for this age determination is not indicated and no new geochronological information was produced as part of this study. It is probable the formation was deposited between the Neogene and the Quaternary; more work is required to fully understand the age relationships in this part of the stratigraphy.

\subsubsection{Kallang Group}

The Kallang Group (or Kallang Formation), which represents the youngest part of the stratigraphy in Singapore (Fig. 3), unconformably overlies the Bedok Formation and, locally, all other older strata. The Kallang Group (Formation) is described as having five internal units, including: the reef, transitional, littoral, alluvial and marine members (Pitts, 1984). It is 
thought the Kallang Group represents a Quaternary succession ('late Pleistocene and Recent' in Pitts, 1984), and is therefore much younger than other units in Singapore. The sediments of the Kallang Group were not examined as part of this study; however, work to create a revised allostratigraphical framework for the group is ongoing (Chua et al., in prep).

\subsection{Discussion}

The sedimentary rocks of Singapore have a complex and diverse history, recording depositional processes and events in a number of different sedimentary basins and the effects of at least two different tectonic regimes. Through the analysis of this data and the construction of the lithostratigraphical framework of Singapore a number of significant geological events have been identified that have the potential to contribute to the overall geological understanding of Southeast Asia.

\subsection{The Sajahat Formation}

The argillites and quartzites of the Sajahat Formation are thought have been deposited as thin-bedded turbidites (Oliver and Gupta, 2017), possibly in a deep sea fan (Oliver and Gupta, 2019). This meta-sedimentary succession represents the most likely candidate for the basement rocks into which the Bukit Timah Centre was intruded (as described in Gillespie et al., this issue).

\subsection{Singapore's Record of Deposition in the Semantan Basin}

Deposition within the Semantan Basin is recorded in the rocks of Singapore through the Jurong and Sentosa Groups and the Buona Vista Formation.

\subsubsection{The Jurong Group}

The earliest deposition in the Semantan Basin, recorded in Singapore, is documented by the Tuas Formation. This formation records deposition within a shallow marine, carbonate platform or shelfal setting (Fig. 13A). It is characterised by a mixture of low-energy 
carbonate deposits and interbedded siliciclastic sediment, forming typically cyclical packages. The siliciclastic material was brought into the setting by in-draining fluvial systems and was subsequently reworked in a shallow marine environment. The introduction of siliciclastic material may have periodically acted to shut-down carbonate production. The effects of volcanism were relatively small during this time, signified by a general absence of interbedded tuffaceous material suggesting a relatively stable platform. The cyclical nature of the carbonate and siliciclastics deposits is likely related to variations in relative sea level and siliciclastic supply. Overall, the formation records a shallowing-upwards pattern.

The succeeding Pulau Ayer Chawan Formation records deposition in a predominantly deep, but occasionally shallow, marine environment (Fig. 13B). The deep marine deposits include hemi-pelagic mudstones, medial to distal turbidite fans, and debris flow cones. The shallow marine deposits, represented by lenticular-bedded sandstones and siltstones, accumulated on a distal shelf that was well below the storm wave base. The two environments alternated as the succession accumulated, probably due to fluctuations in relative sea level. These sediments represent the most-distal (deepest-water) deposits observed within the Singapore sector of the Semantan Basin.

The transition from a shallow marine carbonate environment of the Tuas Formation into the deep marine setting of the Pulau Ayer Chawan Formation signifies a deepening event within the Semantan Basin during this time. The boundary between the Pulau Ayer Chawan Formation and the underlying Tuas Formation is conformable but quite abrupt, indicating a sudden change in water depth. This may be related to rapid generation of accommodation space through tectonic subsidence and/or through a eustatically influenced rise in relative sea level, both of which may have contributed to the transgression of the shallow marine shelf of the Tuas Formation. 
Evidence for an increasingly unstable shelfal environment during the deposition of the Pulau Ayer Chawan Formation is provided by an upwards increase in the occurrence of thickly-bedded volcanogenic deposits, debrites, and soft sediment deformation. Together, these observations suggest significant tectonic, seismic, and volcanic instability, which were likely associated with the nearby active volcanic arc.

Concomitant with deposition of the Pulau Ayer Chawan Formation, the Nanyang Member was forming through a series of sub-aqueous eruptions from a subsea vent ( $c f$. Yamagishi, 1991) within the deep to shallow marine environment (Fig. 13B). This resulted in the immediate quenching of hot magmas by cold sea water, forming a layered succession of palagonite tuffs and interstitial pillows (hyaloclastites). Their layered and normally graded character likely represents multiple eruption events or could be attributed to reworking on the flanks of a volcanic edifice. The possibility of the Nanyang Member forming through effusive eruptions on land, draining into a basin, forming prograding lava deltas ( $c f$. Watton et al., 2013) cannot be discounted, although given the deep marine characteristics of the surrounding sediments of the Pulau Ayer Chawan Formation, the model of a subsea vent may be more likely. Future work is required in order to determine the exact nature of the hyaloclastite of the Nanyang Member.

The next period of deposition in Singapore is recorded by the Pandan Formation which documents deposition in a shallow marine, carbonate lagoon environment (Fig. 13C). The sharp and likely disconformable boundary between the Pulau Ayer Chawan Formation and the overlying Pandan Formation (Fig. 3) indicates an abrupt shallowing in relative sea level, likely through the reconfiguration of basin margin geometries subsequent to the eruption and formation of the preceding Nanyang Member. In this setting, sparsely distributed allochemrich zones, comprising ooids and pisoids, indicate environmental perturbations resulting in shoaling and/or short periods of high bio-productivity. 
Contemporaneously, deposition of thickly-bedded volcanic deposits of the Kent Ridge Member were being formed by sub-aerial pyroclastic flows that travelled into the carbonate lagoon (Fig. 13C). These deposits provide evidence for near-field eruptive volcanism adjacent to the low energy, stable carbonate environment. The eruptions introduced vast quantities of material into the basin that may have led to a temporary re-alignment of the palaeo-shoreline. The thickest intervals of this member are interpreted as the product of major, caldera-forming eruptions (Gillespie et al., this issue). Thinner intervals may represent the distal products of the same eruption, or the products of smaller eruptions that preceded or succeeded the main eruption; however, thickness may simply be a function of palaeo-seafloor topography.

The transition into the overlying Boon Lay Formation is marked by the re-introduction of clastic material into this region of the Semantan Basin, eventually culminating in the dominance of siliciclastic deposition and associated shut-down of carbonate production. The Boon Lay Formation was deposited in a range of sedimentary environments, from shallow marine to marginal-marine at the base, transitioning into a more terrestrial-dominated environment toward the top (Fig. 13D). The sediment was transported predominantly by indraining fluvial systems and was subsequently re-worked in the marginal-marine and shallow marine settings.

The Boon Lay Formation displays evidence for short-lived rises in relative sea level throughout, represented by periodic marine transgressions into the marginal marine and fluvial settings. Evidence for marine transgressions is provided by the positive identification of bivalves Lopha cristagalli (Linnaeus), Halobia and Mysidioptera identified in BH2F3, found within thicker intervals of mudstone and interbedded flaser-laminated sandstones. These relatively short-lived marine incursions are superimposed on an overall shallowingupwards pattern that typifies the Boon Lay Formation. Consequently, the upper-most parts of 
the Boon Lay Formation are more terrestrially-dominated. The cause of this shallowing upwards may have been related to limited development of accommodation space in the Semantan Basin.

The well-developed volcanic landscapes of the Clementi Member are interpreted as the fully terrestrial part of the Boon Lay Formation (Fig. 13D), formed coevally with the marginal and shallow marine parts. The well-developed, reddened palaeosols that dominate the unit indicate a well-drained floodplain. Two types of palaeosols have been identified: Ultisols and Alfisols (palaeosol classification after Retallack, 1994) dominate in the stratigraphically lower part, while Andisol units and pyroclastic rocks dominate in the upper part, suggesting an increase in volcanic activity over time. Each Andisol unit typically takes 10,000 to 100,000 years to form in a tropical climate (Solleiro-Rebolledo et al., 2015) and therefore represents a long period of non-deposition. These palaeosols are interbedded with channelised sandstone units, likely deposited by fluvial systems, and layers of pyroclastic rock. Most of the channelised units consist of fine- to medium-grained sandstone, suggesting a relatively low-energy, meandering fluvial system. Occasional beds of carbonate-rich, palustrine, and lacustrine sediment, suggest standing water developed from time to time, drying-out periodically to create carbonate nodules and mudcracks in the sediment. Clementi Member deposition passes in and out of the marginal and shallow marine Boon Lay Formation. As the proportion of Andisol and pyroclastic rock increases upwards however, the evidence for marine transgression decreases, suggesting the volcanic events may have altered the coastal geomorphology. It is likely that there is a causal link at this time between volcanic activity, uplift of the hinterland, and input of clastic material into the basin. Age information from the two formations suggests the volcaniclastic Pengerang Formation and Clementi Member are broadly contemporaneous, although the former is not likely part of the Semantan Basin fill. 


\subsubsection{The Sentosa Group}

The boundary between the Jurong Group and the Sentosa Group is separated by an unconformity, which is not observed in core or outcrop, but is inferred from a c. 30 Ma time gap in deposition (Fig. 3). It is possible this unconformity is related to slab break-off below the volcanic arc, which resulted in a regional-scale uplift event during this time (Leslie et al., this issue). Sediments of the Sentosa Group, which outcrop on Sentosa Island, were previously examined and interpreted for depositional environment and palaeogeography. Vilpponen (1988) suggested a 'transgressive beach or shore environment', whereas Oliver and Prave (2013) interpreted 'a continental red-bed molasse succession recording alluviallacustrine sediments' deposited in a half-graben setting, referred to as Lake Sentosa. This study presents an alternative interpretation of sedimentation and depositional environments during Sentosa Group times; one that takes into account differences in the structural arrangement of Singapore (as discussed in Leslie et al., this volume) and additional sedimentary evidence from the group exposed on neighbouring islands (Fig. 2).

The Tanjong Rimau Formation represents the lowermost unit of the Sentosa Group and was deposited largely under terrestrial fluvial conditions. It records the return of large volumes of immature sediments into the Singapore region of the Semantan Basin, signifying active erosion of an uplifted hinterland. The sediment was transported predominantly through braided to meandering fluvial systems (Fig. 13E) that produced thick, trough cross-bedded to planar cross-bedded sandstones as a series of longitudinal bars, transverse bars, point bars, and channel elements. Thinly interbedded, laminated mudstone and very fine-grained sandstones represent some element of overbank preservation. These fluvial systems may have eroded into and re-worked the underlying Jurong Group strata. The stratigraphically highest parts of the Tanjong Rimau Formation display upwards-increasing evidence of marine indicators including: Skolithos burrows (Fig. 12A); flaser lamination (Fig. 12B); hummocky 
cross-stratification (Fig. 12C); reactivation surfaces in cross-bedded sandstones that display opposing foreset dips and thin mud-drapes, reminiscent of herringbone cross-stratification (Fig. 12D), together suggesting a progressive marine incursion into the fluvial setting during this time. This is supported by the interpretation of a 'beach' or 'shore' environment, observed in outcropping sediments on Sentosa Island by Vilpponen (1988). This marine incursion event may have been related to retarded uplift rates following the initial slab breakoff, accompanied by eustatically influenced rise in sea level in the late Triassic.

The transition from the Tanjong Rimau Formation into the overlying Fort Siloso Formation depositional environment is marked by the final dominance of marine process over fluvial process and upwards absence of coarse-grained sediments. The Fort Siloso Formation was deposited in a low energy, marginal marine to fluvio-deltaic/fluvio-lacustrine setting (Fig. 13F) where tidal processes influenced deposition. A low-energy, tidal flat likely surrounded a suite of low-relief tidal channels, depositing repeated successions of very finegrained sands, formed inclined heterolithic stratification (cf. Thomas et al., 1987; Hovikoski et al., 2008). The absence of coarser-grained sediments was likely controlled by the flooding of the hinterland during the transgression, resulting in reduced topography in the source area. The transgression probably formed part of a transgressive systems tract during this time, suggesting relative sea level, in the Semantan Basin was heading towards high-stand by late Triassic times.

\subsubsection{The Buona Vista Formation}

The boundary between the Fort Siloso Formation and the overlying Buona Vista Formation could be interpreted as a disconformity surface, representing a period of hiatus within later stages of development of the Semantan Basin. The Buona Vista Formation was deposited by alluvial and fluvial processes, most likely forming in an alluvial fan setting (Fig. $13 \mathrm{G})$, which often signify major periods of uplift within basins. The size and roundness of the 
clasts in the cobble-grade conglomerate, and the localised preservation of cross-bedded sandstone in borehole core suggests they were water-lain, with limited transportation, likely by high-energy fluvial and/or alluvial processes. Sediments were transported into adjacent depocentres by a mixture of debris flow and fluvial processes, where they were then preserved.

The Buona Vista Formation occurs within spatially restricted areas immediately north of the Murai and Pasir Laba thrusts (Leslie et al., this issue.). The geographical association between these major thrust structures, combined with the locally intensely-deformed nature of the rock in zones up to $c .5 \mathrm{~m}$ thick, suggests a genetic link between these sediments and the fold and thrust deformation structures (Leslie et al., this issue.). The diverse clast assemblage within the conglomerates, along with the observed detrital zircon dates, testifies to a highly mixed sediment source area. Therefore, the Buona Vista Formation is interpreted as syn-orogenic conglomerate and sandstone units, deposited in alluvial fan systems that drained off and across emerging thrust structures (Fig. 13G) during the Late Triassic-Early Jurassic orogenic event.

\subsubsection{Semantan Basin Depositional Summary and Correlation}

The Jurong Group records an overall shallowing upwards pattern with the oldest deposits forming in deep-marine to shallow-marine settings, succeeded by progressive in-filling of the Semantan Basin. Sedimentation was taking place during basin-closure, which was largely controlled by contemporaneous compressional tectonics (see Leslie et al., this issue), resulting in the gradual size reduction of the sediment-sink. Regional-scale, thermally-driven uplift may also have played a role in gradual basin shallowing in response to intrusion of igneous bodies. All of these factors can ultimately be linked to the large-scale closure of the Palaeo-Tethys Ocean (as described in Sone and Metcalfe, 2008). Sentosa Group sediments rest unconformably on Jurong Group strata following a break in deposition within the 
Semantan Basin. The final deposition in this basin is recorded by syn-orogenic conglomerates of the Buona Vista Formation, formed as the compressional features breached the land surface, supplying immature sediments through alluvial fan and fluvial systems deposited on the Jurong and Sentosa group strata. These later stages of deposition may reflect uplift and erosion of the mature arc, perhaps after slab break-off had occurred towards the end of the Upper Triassic (Leslie et al., this issue).

The Jurong Group strata are readily correlated on the basis of lithology, age, and deformation record with the 'Jurong Formation' in South Johor (cf. Lee et al., 2004). More widely, these sedimentary packages can be correlated with the stratigraphy of the Semantan Formation (basin) in Peninsular Malaysia (Jaafar, 1976; Khoo, 1983; Metcalfe, 1990; Hutchison and Tan, 2009; Metcalfe, 2013; Metcalfe 2017a, 2017b).

\subsection{The Kusu and Bukit Batok Formations - Regional Correlation and the Tembeling Basin}

Following the final closure of Palaeo-Tethys, a relatively significant hiatus in sedimentation occurred in Singapore. This hiatus probably persisted until extensional/transtensional tectonism began to affect the area during early Cretaceous and into the Cenozoic (Hutchison and Tan, 2009; Leslie et al., this issue). This new regime led to the formation of a new basin, permitting the deposition and preservation of younger, undeformed sedimentary successions on top of the older, deformed strata of the Semantan Basin. In Singapore, the Kusu Formation and Bukit Batok Formation represent this Lower Cretaceous sedimentary package.

The sediments of the Kusu Formation were deposited within a braided fluvial system that introduced coarser-grained clastic material into the basin. The presence of: abundant metamorphic clasts in these deposits sourced from an emergent meta-sedimentary hinterland; evidence for down-cutting of fluvial systems; and age dating of $\leq 145 \pm 1$ Ma for the Kusu 
Formation ( $\mathrm{Ng}$ and Oliver, unpublished data, cited in Oliver and Gupta, 2019), suggest a period of uplift in the region during the early Cretaceous.

The unconformable, overlying sedimentary succession of the Bukit Batok Formation was deposited by a large, distributive river delta (Fig. 13H). The large size of the fluvial system is inferred from the ubiquitous moderately- to well-sorted nature of the sandstone, implying these sediments were transported significant distances. The abundant organic material preserved in the finer-grained sediments may have accumulated in: isolated and anoxic lacustrine bodies that show evidence for liquefaction (soft-sediment deformation); channel cut-offs in a fluvial environment; or in standing bodies of water that typically form in a deltatop or flood plain settings. These strata are only known in Singapore to the north-west of the Henderson Road Fault and in close spatial proximity to the Bukit Timah Fault Zone (BTFZ; inset to Fig. 10; Leslie et al., this issue), suggesting a measure of local fault control on the distribution. Such faulting could potentially be linked to the strike-slip displacements that were becoming important across the wider region during the Cretaceous ( $c f$. Hutchison, 2007; Hutchison and Tan, 2009). It is possible that the Bukit Batok fluvial system occupied a series of linear depocentres that acted to control the distribution of and eventually, after faulting, conserve this remnant of the sedimentary succession.

These two formations in Singapore can be correlated with post-orogenic, fluviatile-deltaiclacustrine sediments in Peninsular Malaysia, namely the Tembeling Formation (Koopmans, 1968), the Tembeling Group (as defined in Khoo, 1977; Hutchison and Tan 2009), and the Ma'Okil Formation (Loganathan, 1977, 1978; Hutchison and Tan, 2009). On this basis, and for simplicity, the Cretaceous basin that preserved all of these Lower Cretaceous units is hereby referred to as the Tembeling Basin.

5.4 Cenozoic Formations - Insights into deposition 
Sediments from the Cenozoic formations were not examined in this study. However, a few inferences can be made with regards to these formations and their relationship with, and within, the new lithostratigraphical framework.

The character of the Fort Canning Formation has led to past interpretations of it being a discrete colluvial deposit (sensu Shirlaw et al., 2003). In Shirlaw et al. (2003), the apparent absence of corestone weathering in 'Jurong Formation' rocks compared to that observed in igneous rocks (in Singapore) is a key indicator for the Fort Canning Formation being a Cenozoic deposit. However, the apparent close spatial association of the Fort Canning Formation and the Kusu Formation, along with ubiquitous deep-weathering profiles in all formations may allow for a different interpretation. It is possible the 'sandstone boulders' of the Fort Canning Formation, referred to in Pitts (1984) and Shirlaw et al. (1990), are corestones formed in-situ by weathering of Kusu Formation strata. In this scenario, the claygrade matrix may have formed, at least in part, through in-situ weathering of alkali feldspars, originally within the sediments, into clay. Further work should focus on re-examining the Fort Canning Formation in order to test these theories. The source of the boulders within the Fort Canning Boulder Bed having been '...derived from the Unfoliated Kusu Formation' has previously been suggested (Oliver and Gupta, 2019).

The youngest pre-Kallang Group sedimentary deposits in Singapore are represented by the Bedok Formation. The Bedok Formation was likely deposited by alluvial fans that interfingered with laterally adjacent fluvial systems. Reactivation of pre-existing normal faults, particularly at the base of the footwalls along developing normal faults, may have resulted in the rejuvenation of alluvial fan systems. In general, the formation appears to have been derived largely from a granite source, with a smaller contribution from metamorphic basement (Gupta et al., 1987). Consequently, it is inferred to be sourced from localised areas that became uplifted through reactivation of pre-existing faults. The formation is thought to 
be Neogene to early mid-Pleistocene (DSTA, 2009), although there is no direct evidence for the age of the unit in Singapore. Further analysis of these younger formations is required in order to improve the geological understanding in this part of the stratigraphy in Singapore.

\subsection{Conclusions}

- The depositional record of the bedrock geology in Singapore is complex, documenting an diverse suite of sedimentary, structural, and igneous processes represented in the bedrock geology. Despite this, Singapore presents and excellent record of the geological evolution of a forearc basin, including its sedimentary, collisional and post-collisional history.

- A new ICS-compliant lithostratigraphical framework for Singapore has been developed, which comprises three groups, thirteen formations and three members. The new framework provides a record of sedimentation in Singapore that ranges from the Carboniferous (Mississippian), Middle to Upper Triassic, Lower Cretaceous and up until the Quaternary.

- The formations were deposited in a range of sedimentary environments, including deep marine, shallow marine, marginal marine, and fluvial settings, indicating a diverse and dynamic suite of basin-fill successions.

Mesozoic deposition occurred within two main basins: the Middle Triassic to Lower Jurassic Semantan Basin and the younger, Lower Cretaceous Tembeling Basin. Sedimentary processes during Semantan basin times were influenced by a tectonically-active setting that received the ejecta products and effects of the adjacent volcanic arc system.

\section{Acknowledgements}


Many colleagues in the British Geological Survey and collaborators in Singapore have contributed to this study, given freely of their advice, and provided the local knowledge so important to understanding Singapore's geology. The authors specifically thank KoKo Lat, Lau Sze Ghiong, Lim Yong Siang, Kyaw Kyaw Zin, Zaw Min Hlaing for their help and input during the project. We would like to acknowledge Kiso-Jiban Consultants Co Ltd for their assistance and considerable contribution to the investigative works on the geology of Singapore. We would like to acknowledge Grahame Oliver for the highly useful, thoughtprovoking and informative discussions concerning all aspects of the geology of Singapore. BGS staff Craig Woodward and Keith Henderson are thanked for the drafting of figures. BGS staff Jim Riding and Mark Woods are thanked for fossil identification. Ian Metcalfe and Grahame Oliver are thanked for thoughtful and critical reviews, which greatly improved the manuscript. The paper is published by permission of the executive directors of the British Geological Survey (UKRI) and the Building and Construction of Authority of Singapore (BCA). 


\section{References}

Abdullah, N. T., 2009. Mesozoic Stratigraphy. In Hutchison, C.S. and Tan, D. N. K. (Eds.), Geology of Peninsular Malaysia. Kuala Lumpur: University of Malaya and Geological Society of Malaysia.

Ahmad, J., 1976. The geology and mineral resources of the Karak and Temerloh areas, Pahang. Geological Survey of Malaysia District Memoir 15, 127.

Alexander, F. E. S., 1950. Report on the availability of granite on Singapore and the surrounding islands. (Singapore: Government Publications Bureau).

Burton, C.K., 1964. The older alluvium of Johore and Singapore. Journal of Tropical Geography 18, 30-42.

Burton, C. K., 1973a. Mesozoic. 97-142 in Geology of the Malay Peninsula (West Malaysia and Singapore). Gobbett, D. J. and Hutchison, C. S. (Eds.). (Wiley-Interscience)

Burton, C. K., 1973b. Geology and mineral resources. Johore Bahru-Kulai area, South Johore. (Geological Survey of Malaysia).

Chin, F., 1965. The Upper Triassic sediments of Pasir Panjang-Jurong area of Singapore. (Unpublished Honours Thesis, University of Malaya).

Chua, S. Switzer, A.D., Horton, B.P., Chiam, S.L., Kearsey, T.I., Bird, M. and Sieh, K., in prep. A revised Quaternary Stratigraphy of the Kallang River Basin, Singapore. Journal of Quaternary Science, in prep.

DSTA., 2009. Geology of Singapore 2nd Edition. Defence Science and Technology Agency. Fontaine, H. and Lee, K. W., 1993. A Triassic limestone ("Pandan limestone") discovered by drilling at Singapore. CCOP Newsletter, 18, 9-19. 
Foo, K.Y., 1983. The Palaeozoic sedimentary rocks of Peninsular Malaysia - stratigraphy and correlation. Proceedings of the workshop on stratigraphic correlation of Thailand and Malaysia, 1: Technical papers, Geological Society of Thailand \& Geological Society of Malaysia, 1-19.

Gillespie, M. and Styles, M., 1999. BGS rock classification scheme, Volume 1. Classification of igneous rocks. British Geological Survey Research Report, (2nd edition) RR 99-06.

Gillespie, M.R., Kendall, R.S., Leslie, A.G., Millar, I.L., Dodd, T.J.H., Kearsey, T.I., Bide, T., Dobbs, M.R., Chenery, S.R.N., Lee, M.K.W. and Chiam, K.S.L., this issue. The igneous rocks of Singapore: new insights to Palaeozoic and Mesozoic assembly of the Sukhothai Arc. Journal of Asian Earth Sciences, this issue.

Gupta, A., Rahman, A., Wong, P. P. and Pitts, J., 1987. The Old Alluvium of Singapore and the extinct drainage system to the South China Sea. Earth Surface Processes and Landforms, $12,259-275$.

Hall, R., 2009. The Eurasian Southeast Asian margin as a modern example of an accretionary orogen. 351-372 in Earth Accretionary Systems in Space and Time. Cawood, P. A. and Kroner, A. (editors). Geological Society Special Publication, 318 (London: Geological Society of London).

Hall, R,, 2012. Late Jurassic - Cenozoic reconstructions of the Indonesian region and the Indian Ocean. Tectonophysics, 570-571, 1-41.

Hallsworth, C.R. and Knox, R., 1999. BGS rock classification scheme. Volume 3, classification of sediments and sedimentary rocks. British Geological Survey Research Report, RR 99-03. 
Ismail H.H., Madon, M. and Bakar, Z. A. A., 2007. Sedimentology of the Semantan Formation (Middle - Upper Triassic) along the Karak-Kuantan Highway, central Pahang. Geological Society of Malaysia, Bulletin, 53, 27-34.

Hovikoski, J., Ra“sa”nen, M., Gingras, M., Ranzi, A. and Melo, J., 2008. Tidal and seasonal controls in the formation of Late Miocene inclined heterolithic stratification deposits, western Amazonian foreland basin. Sedimentology, 55, 499-530.

Hutchison, C.S., 2007. Geological Evolution of South-East Asia, second edition, Geological Society of Malaysia, Kuala Lumpur, 433.

Hutchison C.S. and Tan D.N.K., 2009. Geology of Peninsular Malaysia, C.S. Hutchison and D. N. K. Tan (Eds.). University of Malaya/Geological Society of Malaysia, Kuala Lumpur.

Jaafar A., 1976. Geology and mineral resources of the Karak and Temerloh areas, Pahang. Geological Survey of Malaysia District Memoir, 15, 127.

Khoo, H.P., 1977. The geology of the Sungai Tekai area. Geological Survey of Malaysia Annual Report, 93-103.

Khoo, H.P., 1983. Mesozoic Stratigraphy in Peninsula Malaysia. In: Proceedings of the workshop on stratigraphic correlation of Thailand and Malaysia, 1: Technical papers, Geological Society of Thailand \& Geological Society of Malaysia, 270-383.

Kobayashi, T. and Tamura, M., 1968. Upper Triassic Pelecypods from Singapore. Geology and Palaeontology in Southeast Asia 5, 138-150.

Kobayashi, T. and Tamura, M., 1984. The Triassic bivalvia of Malaysia, Thailand and adjacent areas. Geology and palaeontology of southeast Asia, 25, 201-228.

Koopmans, B.N., 1968. The Tembeling Formation - A litho-stratigraphic Description (West Malaysia). Geological Society of Malaysia Bulletin 1, 22-43. 
Lat, K.K., Goay, K.H., Lau, S.G., Chiam, S.L. and Chew, K.C., 2016. A New Lithostratigraphic Framework Proposed for Singapore. Geotechnical Engineering Journal of the SEAGS \& AGSSEA 47, 3, 70-73.

Lee, C.P., Leman, M. S., Hassan, K., Nasib, B.M. and Karim, R., 2004. Stratigraphic Lexicon of Malaysia. (Geological Society of Malaysia; Kuala Lumpur).

Leslie, A.G., Dodd, T.J.H., Gillespie, M.R., Kendall, R.S., Bide, T.P., Dobbs, M.R., Kearsey, T.I., Lee, M.K.W. and Chiam, S.L., this issue. Ductile and brittle deformation in Singapore: a record of Mesozoic orogeny and amalgamation in Sundaland, and of post-orogenic faulting. Journal of Asian Earth Sciences, this issue.

Liew, T.C. and McCulloch, M.T., 1985. Genesis of granitoid batholiths of Peninsular Malaysia and implications for models of crustal evolution: Evidence from a Nd-Sr isotopic and U-Pb zircon study. Geochimica et Cosmochimica Acta, 49, 587-600.

Loganathan, P., 1977. The Geology and Mineral resurces of the Segamat Area (Sheet 115), Johore. Geological Survey of Malaysia Annual Report, 104-107.

Loganathan, P., 1978. The Ma'Okil Formation - an outlier of the Tahan supergroup. Geological survey of Malaysia Annual Report, 104-107.

Metcalfe. I, Sivam, S. P. and Stauffer, P. H., 1982. Stratigraphy and sedimentology of the Middle Triassic rocks exposed near Lanchang, Pahang, Peninsular Malaysia. Geological Society of Malaysia Bulletin 15, 19-30.

Metcalfe, I., 1990. Stratigraphic and tectonic implication of Triassic conodonts from northwest Peninsular Malaysia. Geological Magazine 127, 567-578.

Metcalfe, I., 2011. Palaeozoic-Mesozoic history of Southeast Asia. In Hall, R., Cottam, M. A. and Wilson, M. E. J. (Eds.), The Southeast Asian Gateway: History and Tectonics of the 
Australia-Asia Collision. Geological Society of London Special Publication 355, 7-35. (London: Geological Society of London).

Metcalfe, I., 2013. Tectonic Evolution of the Malay Peninsula. Journal of Asian Earth Sciences 76, 195-213.

Metcalfe, I., 2017a. Tectonic evolution of Sundaland. Bulletin of the Geological Society of Malaysia 63, 27-60.

Metcalfe, I. 2017b. Devonian and Carboniferous stratigraphy and conodont biostratigraphy of the Malay Peninsula in a regional tectonic context. Stratigraphy, 14, 259-283.

Murphy, M.A. and Salvador, A., 1999. International Stratigraphic Guide - An abridged version. Episodes 22, 255-272.

Newton, R.B., 1923. XXXIII.-On marine Triassic shells from Singapore. Annals and Magazine of Natural History, 12, 300-321.

Ng, S. W. P., Whitehouse, M. J., Searle, M. P., Robb, L. J., Ghani, A. A., Chung, S. L., Oliver, G. J.H., Sone, M., Gardiner, N. J. and Roselee, M. H., 2015a. Petrogenesis of Malaysian granitoids in the Southeast Asian tin belt: Part 1. Geochemical and Sr-Nd isotopic characteristics. Geological Society of America Bulletin, 127, 1209-1237.

Ng, S. W. P., Whitehouse, M. J., Searle, M. P., Robb, L. J., Ghani, A. A., Chung, S. L., Oliver, G. J.H., Sone, M., Gardiner, N. J. and Roselee, M. H., 2015b. Petrogenesis of Malaysian granitoids in the Southeast Asian tin belt: Part 2. U-Pb zircon geochronology and tectonic model. Geological Society of America Bulletin, 127, 1238-1258.

Nowson, W. J. R., 1954. The history and construction of the foundation of the Asia Insurance Building, Singapore. Proceedings, The Institution of Civil Engineers Part 1, 3, 407-456. 
Oliver, G. and Prave, T., 2013. Palaeogeography of Late Triassic red-beds in Singapore and the Indosinian Orogeny. Journal of Asian Earth Sciences 76, 214-224.

Oliver, G. J. H., Zaw, K., Hotson, M., Meffre, S. and Manka, T., 2014. U-Pb zircon geochronology of Early Permian to Late Triassic rocks from Singapore and Johor: A plate tectonic reinterpretation. Gondwana Research 26, 132-143.

Oliver, G.J.H. and Gupta, A., 2017. A Field Guide to the Geology of Singapore. $1^{\text {st }}$ Edition. Lee Kong Chian Natural History Museum, National University of Singapore, Singapore.

Oliver, G.J.H. and Gupta, A., 2019. A Field Guide to the Geology of Singapore. $2^{\text {nd }}$ Edition. Lee Kong Chian Natural History Museum, National University of Singapore, Singapore.

Pan, X., Oliver, G.J.H., Chu, J., Goh, K.H., Wei, X. and Kumarasamy, J., 2018. Zircon age dating of the Sajahat Formation from Punggol, Singapore. 10th Asian Rock Mechanics Symposium The ISRM International Symposium, $29^{\text {th }}$ Oct $-03^{\text {rd }}$ Nov 2018, Singapore.

Pitts, J., 1984. A review of geology and engineering geology in Singapore. Quarterly Journal of Engineering Geology and Hydrogeology 17, 93-101

P.W.D., 1976. Geology of the Republic of Singapore. (Singapore: Public Works Department, Singapore).

Rajah, S.S., 1986. The Geology and Mineral Resources of the Gunung Belumut Area, Johore. Geological Survey of Malaysia District Memoir 19, 191.

Retallack, G.J., 1994. The environmental factor approach to the interpretation of paleosols. SSSA Special Publication, 33, 31-31.

Robertson, S.J., 1999. BGS rock classification scheme. Volume 2, Classification of metamorphic rocks. British Geological Survey Research Report, RR 99-02. 
Sevastjanova, I., Clements, B., Hall, R., Belousova, E. A., Griffin, W. 1. and Pearson, N., 2011. Granitic magmatism, basement ages, and provenance indicators in the Malay peninsula: Insights from detrital zircon $\mathrm{U}-\mathrm{Pb}$ and Hf-isotope data. Gondwana Research 19, 1024-1039.

Sevastjanova, I., Hall, R., Rittner, M., Paw, S.M.T.L, Naing, T.T., Alderton, D.H. and Comfort, G., 2016. Myanmar and Asia united, Australia left behind long ago. Gondwana Research 32, 24-40.

Searle, M. P., Whitehouse, M. J., Robb, L. J., Ghani, A. A., Hutchison, C.S., Sone, M., Ng, S. P., Roselee, M. H., Chung, S.L. and Oliver, G. J. H., 2012. Tectonic evolution of the Sibumasu-Indochina terrane collision zone in Thailand and Malaysia: constraints from new $\mathrm{U}-\mathrm{Pb}$ zircon chronology of Southeast Asian tin granitoids. Journal of the Geological Society $169,489-500$.

Scrivenor, J. B., 1924. The geology of Singapore Island. Journal of the Malayan Branch of the Asiatic Society 2, 1-8.

Shirlaw, J. N., POH, K. B. and Hwang, R. N., 1990. Properties and Origins of the Singapore Boulder Bed. Tenth Southeast Asian Geotechnical Conference, 16-20 April, Taipei (conference paper).

Shirlaw, J. N., Broome, P. B., Chandrasegaran, S., Daley, J., Orihara, K., Raju, G. V. R., Tang, S. K., Wong, I. H., Wong, K. S. and Yu, K., 2003. The Fort Canning Boulder Bed. (Underground Singapore 2003 Engineering Geology Workshop).

Solleiro-rebolledo, E., Sedov, S. and Cabadas-báez, H., 2015. Use of soils and palaeosols on volcanic materials to establish the duration of soil formation at different chronological scales. Quaternary International 376, 5-18. 
Sone, M. and Metcalfe, I., 2008. Parallel Tethyan sutures in mainland Southeast Asia: New insights for Palaeo-Tethys closure and implications for the Indosinian orogeny. Comptes Rendus Geoscience 340, 166-179.

Stauffer, P. H., 1973. Cenozoic. In: Gobbett, D. J. and Hutchison, C. S. (Eds.), Geology of the Malay Peninsula, 143-176. (New York: Wiley-Interscience)

Thomas, R.G., Smith, D.G., Wood, J.M., Visser, J., Calverly- Range, E.A. and Koster, E.H., 1987. Inclined heterolithic stratification; terminology, description, interpretation and significance. Sedimentary Geology 53, 123-179.

Tucker, M.E., 2009. Sedimentary petrology: an introduction to the origin of sedimentary rocks. Third edition, Blackwell Science, Oxford, pp 251.

Vilpponen, A.B., 1988. Sedimentology and Stratigraphy of the Jurong Formation, Singapore. M.A. Thesis, National University of Singapore (unpublished).

Walker, D., 1956. Studies on the Quaternary of the Malay Peninsula. I. Alluvial deposits of Perak and the relative levels of land and sea. Journal Federation Museum, 1 and 2 (New Series), 19-34.

Walker, R.G., 1992. Facies, facies models and modern stratigraphic concepts. Facies models response to sea-level change. In: Walker, R.G., and James, N.P. (eds.), Facies models: response to sea-level change, Geological Association of Canada, 1-14.

Watton, T.J. Jerram, D.A., Thordarson, T. and Davies, R.J., 2013. Three-dimensional lithofacies variations in hyaloclastite deposits. Journal of Volcanology and Geothermal Research 250, 19-33.

Wong, I. H., Ooi, I. K. and Broms, B. B., 1996. Performance of raft foundations for high-rise buildings on the Bouldery Clay in Singapore. Canadian Geotechnical Journal 33, 219-236. 
Yamagishi, H., 1991. Morphological and sedimentological characteristics of the Neogene submarine coherent lavas and hyaloclastites in Southwest Hokkaido, Japan, Sedimentary Geology 74 , $5-23$. 


\section{Figures Captions}

\section{All figures are intended for colour reproduction, on both the web and in print}

Figure 1.) The distribution of major continental blocks, fragments and terranes in the modern-day tectonic settings of Southeast Asia, modified after Metcalfe (2011; cf. Hall, 2009). Singapore lies at the southern end of Peninsular Malaysia. The Bentong-Raub Suture Zone defines the westerly limits of the Eastern and Central belts of Peninsular Malaysia (Metcalfe, 2013, 2017a), and the easterly limit of the Western Belt. The rocks of the Central and Eastern belts record deposition within the Permian to Triassic Sukhothai Arc that now occupies an area between Sibumasu and East Malaya. The bedrock geology of Singapore shares much of its history with that of the Central and Eastern belts.

Figure 2.) The distribution of $\mathrm{BCA}$ boreholes and field localities analysed as part of this study. The location of stratotype sections, in both borehole and as field localities, has been provided (in yellow); supporting information for these is contained within Table 1. In general, this study focuses on the boreholes and field localities in the southern and western parts of Singapore. The results of the analysis of boreholes and field localities in the northern and eastern areas are presented in Gillespie et al. (this issue). Noteworthy locations, pertinent to this study, include: Jurong Island, Telok Blangah Park, Sentosa Island, Pulau Tekukor, Fort Canning Park, Kusu Island, Pulau Tekong, and Pengerang.

Figure 3.) The ICS compliant lithostratigraphical framework for Singapore developed in this study. The lithostratigraphical framework contains three groups, thirteen formations, and three members. In addition, 'depositional age' information, including new U-Pb age determinations of both eruptive and detrital zircons (green and red text, respectively), along with already published geochronological information (blue text), has been summarised per unit. The overall 'depositional environment' for each formation, regional-scale 'formation 
level correlative units' (mainly using Hutchison and Tan, 2009), and observed 'geological events' that may have regional-scale geological implications have been described per unit (BGS @ UKRI 2019).

Figure 4.) Kernel Density Estimation (KDE) plots of samples analysed for detrital zircon, U$\mathrm{Pb}$ age determination, by formation. In general, the samples from the Tanjong Rimau, Buona Vista, and Kusu formations each show a single, large peak at their maximum depositional age. In comparsion, the four samples from the Bukit Batok Formation show a highly varied suite of maximums. The results of these analysis, along with the geochronological data from the pyroclastic rocks (from Gillespie et al., this issue), are summarised in Figure 3 (BGS (C) UKRI 2019).

Figure 5.) The distribution of the Jurong Group and Sentosa Group strata across Singapore. Linework, including faults, thrust faults, anticlines, synclines, and stratigraphical boundaries for this map is derived from Leslie et al. (this issue). The Jurong Group and Sentosa Group strata are offset by the southwest-northeast trending Henderson Road Fault (HRF), and both of their northerly limits are defined by the Bukit Timah Fault Zone (BTFZ).

Figure 6.) The distribution of the Jurong Group and it's four composite formations (Tuas Formation, Pulau Ayer Chawan Formation, Pandan Formation, and Boon Lay Formation) and three members (Nanyang Member, Kent Ridge Member, and Clementi Member) across Singapore. Linework, including faults (HRF-Henderson Road Fault; BTFZ-Bukit Timah Fault Zone), thrust faults, anticlines, synclines and stratigraphical boundaries for this map, is derived from Leslie et al. (this issue). BCA boreholes and field localities are shown; labels for these boreholes can be found on Figure 2. The Nanyang Member known distribution (see inset map) is restricted to the area of, and around, Nanyang Technological University (NTU). 
Figure 7.) Example images of borehole core data from the Jurong Group. Each core stick is $1 \mathrm{~m}$ long, with the top of the core in the upper right corner and the base in the lower left corner of each set. A.) Carbonate rocks, sandstone, and mudstone units of the Tuas Formation (BH1A1, 199-191 m). B.) Turbidite sandstone units, pelagic mudstone units and debrite conglomerate units of the Pulau Ayer Chawan Formation (BH2A4, 190-182 m). C.) Hydroclastic lapillistone and lapilli tuff units within the Nanyang Member of the Pulau Ayer Chawan Formation (BH1B2, 85-77 m). D.) Thickly-bedded, micritic, carbonate rocks of the Pandan Formation (BH1A8, 73-65 m).

Figure 8.) Example images of borehole core data from the Jurong Group. Each core stick is $1 \mathrm{~m}$ long, with the top of the core in the upper right corner and the base in the lower left corner of each set. A.) Green, bedded tuff units of the Kent Ridge Member of the Pandan Formation (BH1B6, 190-182 m). B.) Cross-bedded, poor and well-sorted sandstone units, and mottled mudstone units of the Boon Lay Formation (BH1B3, 178-170 m). C.) Reddened, mottled Andisol and Ultisol units within the Clementi Member of the Boon Lay Formation (BH2B15, 105-97 m).

Figure 9.) Example images of borehole core data that contain and document important unit boundaries within the lithostratigraphy, with the top of the core in the upper right corner and the base in the lower left corner of each set. A.) Red coloured silliclastic rocks of the Tanjong Rimau Formation (left), unconformably overlain by the light-grey coloured, finer grained sillisiclastic rocks of the Bukit Batok Formation (right; BH1F5, 149-139 m). B.) Hydroclastic rocks of the Nanyang Member of the Pulau Ayer Chawan Formation (left), unconformably overlain by sillisiclastic sediments of the Buona Vista Formation (right). The boundary is marked by a zone of intense deformation, a dark colouration, and an abrupt change from hydroclastic to silliclastic rocks across the boundary (BH1B2, 67-59 m). C.) Dark red sillisiclastic rocks of the Clementi Member of the Boon Lay Formation (left), 
unconformably overlain by sediments of the Bukit Batok Formation (right; BH2B15, 51$41 \mathrm{~m})$. D.) Pyroclastic tuffs of the Kent Ridge Member of the Pandan Formation (left), unconformably overlain by altered sillisiclastic rocks of the Tanjong Rimau Formation (right; BH1F13, 93-83 m).

Figure 10.) The distribution of the Triassic-aged Tanjong Rimau Formation and Fort Siloso Formation of the Sentosa Group, along with the Buona Vista Formation in Singapore. The distribution of the Kusu and Bukit Batok formations are also shown, along with the likely distribution of the Bedok Formation across Singapore. Linework, including faults, thrust faults, anticlines, synclines and stratigraphical boundaries for this map, is derived from Leslie et al. (this issue). The Sentosa Group strata are mainly encountered south of the Henderson Road Fault (HRF). The Buona Vista Formation strata are found in proximity to broadly northwest-southeast trending thrust faults. The Bukit Batok Formation (see inset) has a limited distribution, along with a spatial association with the Bukit Timah Fault Zone (BTFZ). The younger Kusu and Bedok formations have a spatial association with the Nee Soon Fault (NSF), with the western limit of the Bedok Formation coinciding with this fault for $c .15 \mathrm{~km}$ north to south across Singapore.

Figure 11.) Example images of borehole core data from the Sentosa Group, Buona Vista Formation, and Bukit Batok Formation. Each core stick is $1 \mathrm{~m}$ long, with the top of the core in the upper right corner and the base in the lower left corner of each set. A.) Poorly-sorted, very coarse-grained sandstone units and moderate- to well-sorted, medium-to fine-grained sandstone units of the Tanjong Rimau Formation (BH1F6, 173-165 m). B.) Very well-sorted, very fine-grained to fine-grained, flaser laminated sandstone units and dark brown, mottled, bioturbated mudstone units of the Fort Siloso Formation (BH1F2, 94-86 m). C.) Rounded, up to cobble-grade, matrix and clast-supported conglomerate units and fine-grained, moderateto well-sorted sandstone units of the Buona Vista Formation (BH1B2, 45-37 m). D.) 
Moderate- to well-sorted, mud-clast-rich sandstone units and reddened, mottled, pedogenically-altered sandstone and mudstone units of the Bukit Batok Formation (BH2B15, $45-37 \mathrm{~m})$.

Figure 12.) Example images of outcrop from Sentosa Island, Pulau Tekukor and Telok Blangah Park in Singapore. A.) Vertical, mud-filled Skolithos burrows in a fine-grained, wellsorted sandstone from the upper part of the Tanjong Rimau Formation, exposed on Sentosa Island. B.) Mud-draped ripple cross-lamination structures, representing flaser lamination from the upper part of the Tanjong Rimau Formation, exposed on Sentosa Island. C.) Hummocky cross-stratification (HCS) from the Tanjong Rimau Formation, exposed on Pulau Tekukor. D.) Reactivation surfaces in cross-bedded sandstones, which display opposing foreset dips and thin mud-drapes, reminicent of herringbone cross-stratification. The example is from the upper part of the Tanjong Rimau Formation, exposed on Sentosa Island. E.) The interpreted unconformity between the Tanjong Rimau Formation of the Sentosa Group and the overstepping Kusu Formation, exposed at Telok Blangah Park (BGS @ UKRI 2019).

Figure 13.) $3 \mathrm{D}$, schematic block diagrams of the depositional enviornments for the formations within the new lithostratigraphical framework for Singapore. A.) The shallow marine carbonate platform/lagoon environment of the Tuas Formation. B.) The deep marine to shallow marine environment of the the Pulau Ayer Chawan Formation, which experienced volcanic eruptions from subsea vents that produced the hydroclastic Nanyang Member. C.) The shallow marine carbonate lagoon environment of the Pandan Formation, which periodically received substantial volcaniclastic input through pyroclastic flows that formed the Kent Ridge Member. D.) The shallow marine to terrestrial environment of the Boon Lay Formation and near-field eruptions that formed the volcanic landscape of the interdigitating Clementi Member. E.) The fluival, braided to meandering environment of the Tanjong Rimau Formation. F.) The low energy, marginal marine depositional environment of the Fort Siloso 
Formation, which was deposited following the marine transgression of the underlying Tanjong Rimau Formation. G.) The alluvial fan to fluvial environment of the Buona Vista Formation, which formed immediately around and down-slope from emerging thrust structures, developed during the culmination of the Late Triassic-Early Jurassic orogenic event. H.) The fluvio-deltaic environment of the Bukit Batok Formation, with deposition likely controlled within a series of extensional grabens formed during this time (BGS $\subset$ UKRI 2019).

\section{$\underline{\text { Table Captions }}$}

Table 1.) Diagnostic criteria for the all units within the lithostratigraphical framework of Singapore. For each unit, the unit name and stratotype section have been indicated. The diagnostic features for each unit provide a means of identifying the formation in both borehole core data and in outcrop. The 'Justification for Stratal Position' describes where formation boundaries and the order of succession were observed and established. The estimated thickness for each unit remains one of the key uncertainties in Singapore; these estimated thicknesses are consistent with borehole-derived constraints on the stratigraphical succession, as well as the results of 3D modelling and cross-section construction (Leslie et al., this volume). All unit assignations within each interval in the BCA boreholes are provided in the final column.

Table 2.) The ten critical boreholes that were logged in detail as part of this study, which underpin the lithostratigraphial framework. Consequently, the detailed logs for these boreholes underwent full facies analysis. Most of these boreholes form the stratotype sections for individual, or multiple lithostratigraphical units within the new framwork. The stratotypes borehole cores have been retained by $\mathrm{BCA}$ and are accessible upon request. The location 
information is provided in the table, which are also plotted on the map in Figure 2 (in yellow). 


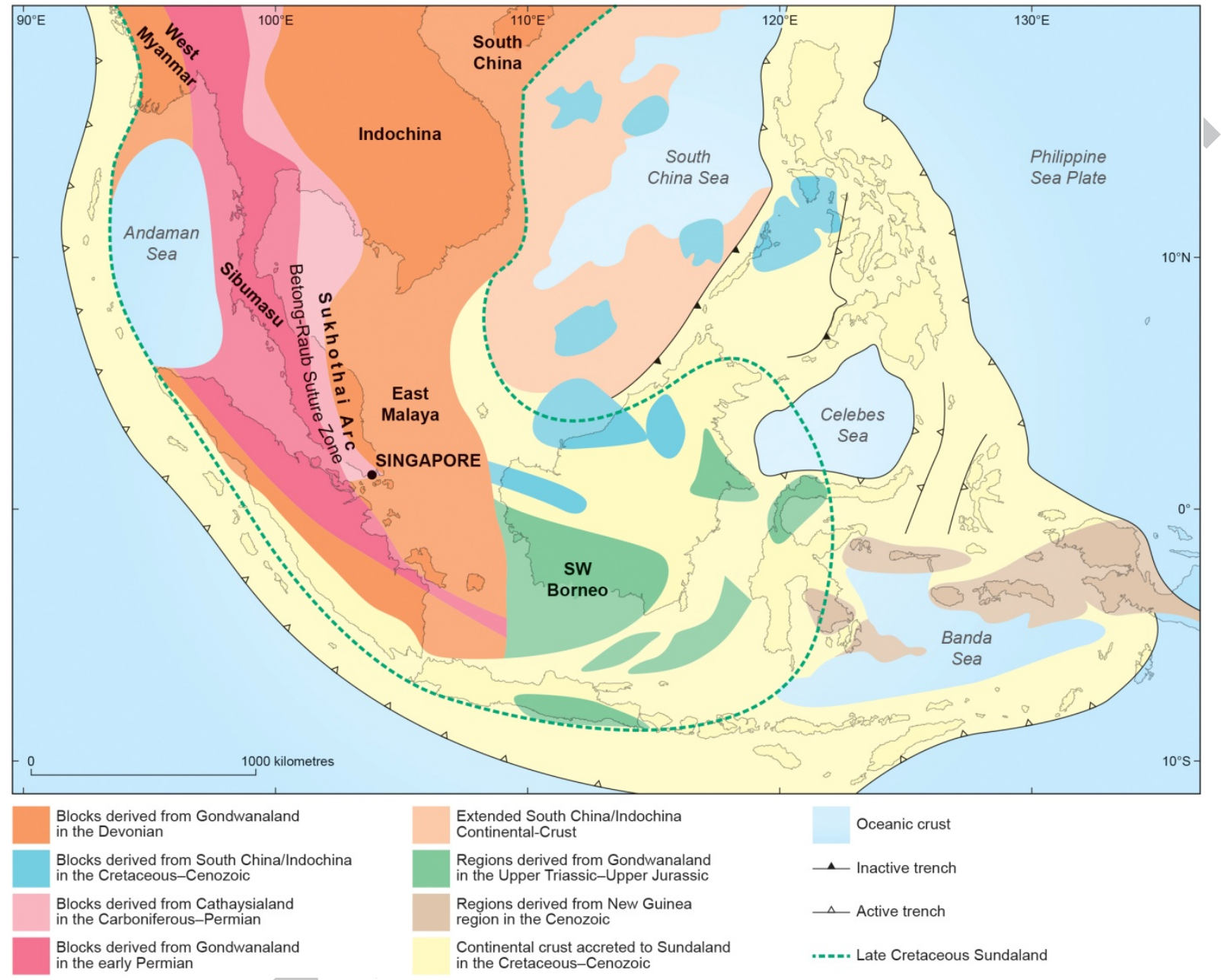




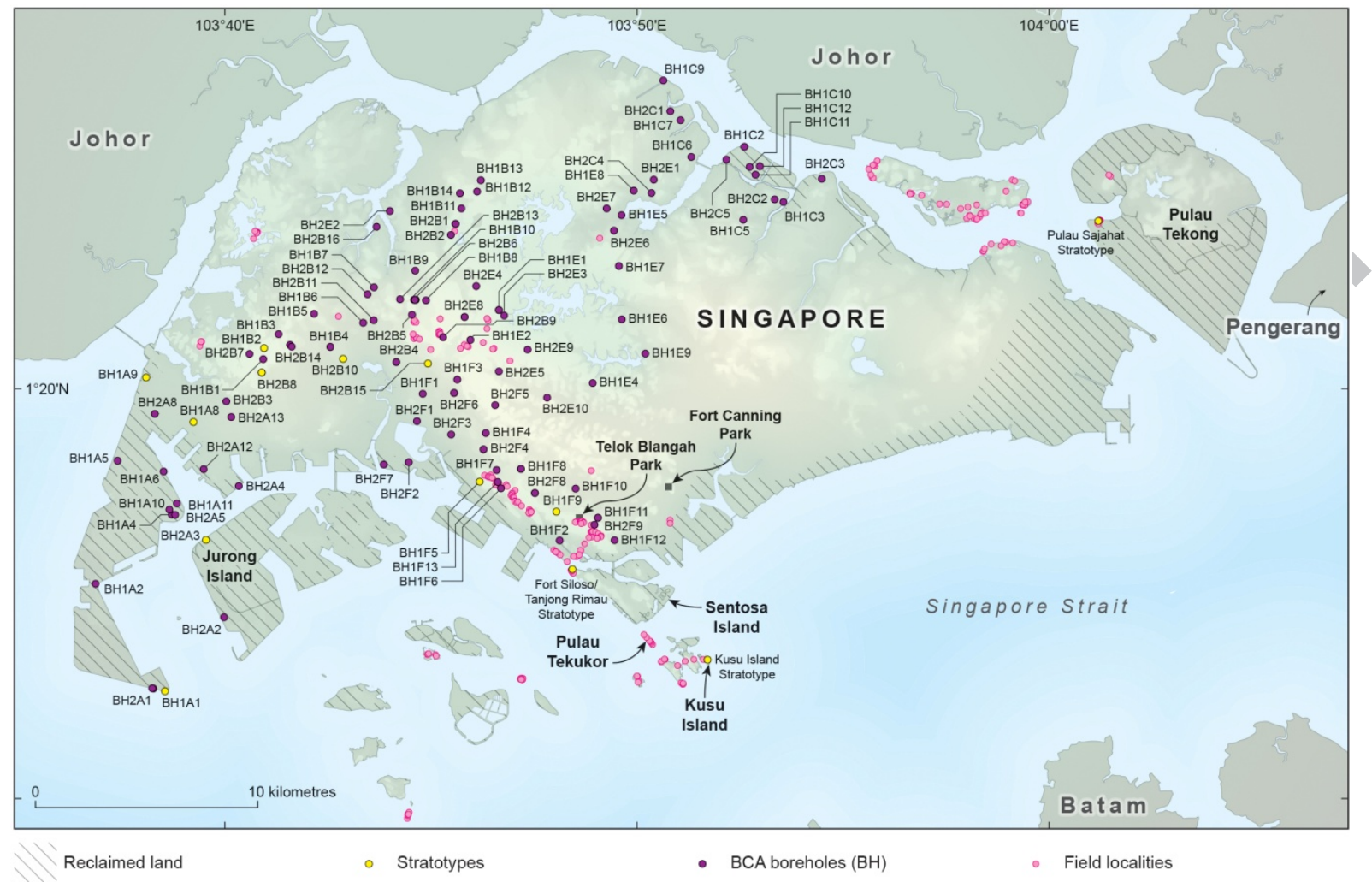




\begin{tabular}{|c|c|c|c|c|c|c|c|}
\hline \begin{tabular}{|l|} 
System/ \\
Epoch
\end{tabular} & \multicolumn{2}{|r|}{$\begin{array}{l}\text { Lithostratigraphical } \\
\text { Framework } \\
\text { for Singapore }\end{array}$} & \multicolumn{2}{|c|}{ Depositional Age } & \multirow[t]{2}{*}{$\begin{array}{l}\text { Depositional } \\
\text { Environment }\end{array}$} & \multirow[t]{2}{*}{$\begin{array}{c}\text { Formation Level } \\
\text { Correlative Units } \\
\text { (Hutchison \& Tan, 2009) }\end{array}$} & \multirow[t]{2}{*}{ Geological Events } \\
\hline Quaternary & 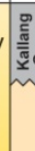 & & & \begin{tabular}{|l|} 
KEY \\
Detrital (this study) \\
EFutive (Glispie et al., this issue) \\
Other published dates
\end{tabular} & & & \\
\hline to & & $\begin{array}{l}\text { Bedok } \\
\text { Formation }\end{array}$ & & & Alluvial to colluvial & $\begin{array}{l}\text { The 'Simpang Formation' } \\
\text { in Johor }\end{array}$ & $\begin{array}{l}\text { Modern weathering } \\
\text { and erosion }\end{array}$ \\
\hline Neogene & & $\begin{array}{l}\text { Fort Canning } \\
\text { Formation }\end{array}$ & & & Deep weathering & $\begin{array}{l}\text { The 'boulder beds' described } \\
\text { in many parts of Peninsular } \\
\text { Malaysia }\end{array}$ & Palaeo-weathering \\
\hline \multirow{2}{*}{$\begin{array}{c}\text { Lower } \\
\text { Cretaceous }\end{array}$} & & $\begin{array}{l}\text { Bukit Batok } \\
\text { Formation }\end{array}$ & $\leq 123 \pm 1 \mathrm{Ma}$ & $\begin{array}{l}\mathrm{BH} 285-\leq 150 \pm 2 \mathrm{Ma} \\
\text { BH1F11- } 5128 \pm 2 \mathrm{Ma} \\
\text { BH2B4 (top) }-\leq 123 \pm 1 \mathrm{Ma} \\
\mathrm{BH} 284 \text { (base) }-\leq 125 \pm 1 \mathrm{Ma}\end{array}$ & Fluvio-deltaic & $\begin{array}{l}\text { Tembeling Formation } \\
\text { Ma' Okil Formation }\end{array}$ & $\begin{array}{l}\text { Widespread fluvio-deltaic } \\
\text { system } \\
\text { Localised fault control }\end{array}$ \\
\hline & & $\begin{array}{l}\text { Kusu } \\
\text { Formation }\end{array}$ & $\leq 145 \pm 1 \mathrm{Ma}$ & $\begin{array}{l}\text { S145 } \pm 1 \mathrm{Ma} \\
\text { S156 } 11 \mathrm{Ma} \\
\text { AGLE_65_02 - } 5225 \pm 2 \mathrm{Ma}\end{array}$ & Fluvial & $\begin{array}{l}\text { Tembeling Group } \\
\text { Ma' Okil Formation }\end{array}$ & $\begin{array}{l}\text { Strike-slip, transtensional } \\
\text { setting, resulting in } \\
\text { isolated basins }\end{array}$ \\
\hline $\begin{array}{l}\text { ?Lower } \\
\text { Jurassic }\end{array}$ & & $\begin{array}{l}\text { Buona Vista } \\
\text { Formation }\end{array}$ & $\begin{array}{c}>198 \pm 2 \mathrm{Ma} \\
\uparrow \\
\leq 245 \pm 2 \mathrm{Ma}\end{array}$ & $\begin{array}{l}\text { Youngest granite at } 198 \pm 2 \text { Ma- } \\
\text { suture and compression completed } \\
\text { by then } \\
\text { BH1B2- } 2245 \pm 2 \mathrm{Ma} \\
\text { Re-worked conglomerates }\end{array}$ & $\begin{array}{l}\text { Alluvial } \\
\text { and fluvial }\end{array}$ & None & $\begin{array}{c}\text { L Orogenic unconformity }- \\
\text { Syn-orogenic } \\
\text { sedimentation }\end{array}$ \\
\hline \multirow{2}{*}{$\begin{array}{l}\text { Upper } \\
\text { Triassic }\end{array}$} & \multirow{2}{*}{ 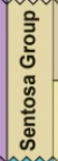 } & $\begin{array}{l}\text { Fort Siloso } \\
\text { Formation }\end{array}$ & \multirow[b]{2}{*}{$\leq 209 \pm 2 \mathrm{Ma}$} & & Marginal marine & None & $\begin{array}{l}\square \text { Onset of thrusting } \square \\
- \text { Marine transgression } \square\end{array}$ \\
\hline & & $\begin{array}{l}\text { Tanjong Rimau } \\
\text { Formation }\end{array}$ & & 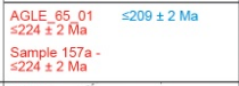 & $\begin{array}{l}\text { Fluvial - braided } \\
\text { to meandering }\end{array}$ & None & $\begin{array}{c}\begin{array}{c}\text { Regional } \\
\text { uplift }\end{array} \rightarrow \begin{array}{c}\text { Active } \\
\text { erosion }\end{array} \\
\text { ?Slab break-off } \\
\end{array}$ \\
\hline \multirow{5}{*}{$\begin{array}{l}\text { Middle } \\
\text { Triassic }\end{array}$} & \multirow{5}{*}{ 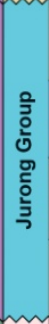 } & $\begin{array}{c}\text { Boon Lay Clementi } \\
\text { Formation } \\
\text { Member }\end{array}$ & \multirow{5}{*}{$242 \pm 3 \mathrm{Ma}$} & 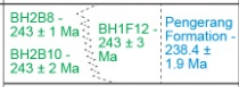 & $\begin{array}{c}\text { Shallow marine to } \\
\text { terrestrial } \\
\text { (inboard volcanic landscape) }\end{array}$ & $\begin{array}{l}\text { Semantan Formation, Central } \\
\text { Belt of Peninsular Malaysia }\end{array}$ & $\begin{array}{l}\text { Volcanism } \\
\text { Re-introduction of } \\
\text { clastic material }\end{array}$ \\
\hline & & \multirow{3}{*}{$\begin{array}{l}\begin{array}{l}\text { Pulau Ayer } \\
\text { Chawan } \\
\text { Formation }\end{array} \\
\text { Member }\end{array}$} & & 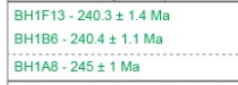 & $\begin{array}{l}\text { Shallow marine } \\
\text { carbonate lagoon }\end{array}$ & $\begin{array}{l}\text { Semantan Formation, Central } \\
\text { Belt of Peninsular Malaysia }\end{array}$ & $\begin{array}{c}\text { Volcanism } \\
\text { Carbonate production } \\
\text { Abrupt shallowing } \\
\end{array}$ \\
\hline & & & & $8 \mathrm{H} 1 \mathrm{~B} 2-245.5 \pm 2.6 \mathrm{Ma}$ & \multirow[t]{2}{*}{$\begin{array}{l}\text { Deep marine to } \\
\text { shallow marine }\end{array}$} & \multirow{2}{*}{$\begin{array}{l}\text { Semantan Formation, Central } \\
\text { Belt of Peninsular Malaysia }\end{array}$} & \multirow{2}{*}{$\begin{array}{c}\text { Increasing volcanism } \\
\text { Deep marine sedimentation }\end{array}$} \\
\hline & & & & BH1A9-245 $\pm 1 \mathrm{Ma}$ & & & \\
\hline & & $\begin{array}{c}\text { Tuas } \\
\text { Formation }\end{array}$ & & $\mathrm{BH} 1 \mathrm{~A} 1-243 \pm 2 \mathrm{Ma}$ & $\begin{array}{c}\text { Shallow marine } \\
\text { carbonate platform }\end{array}$ & $\begin{array}{l}\text { Semantan Formation, Central } \\
\text { Belt of Peninsular Malaysia }\end{array}$ & $\begin{array}{c}\text { Transgression } \\
\uparrow \\
\text { Shallowing upwards }\end{array}$ \\
\hline $\begin{array}{c}\text { Carboniterous } \\
\text { (Mississippian) }\end{array}$ & & $\begin{array}{l}\text { Sajahat } \\
\text { Formation }\end{array}$ & $\begin{array}{c}>285 \mathrm{Ma} \\
\leq 337 \pm 3 \mathrm{Ma}\end{array}$ & $\begin{array}{l}>335 \pm 1 \mathrm{Ma} \\
\leq 337 \pm 3 \mathrm{Ma}\end{array}$ & Not known & $\begin{array}{l}\text { Dohol Formation (also known as } \\
\text { Mersing Beds) and/or Linggiu } \\
\text { Formation in south-east Johor }\end{array}$ & Not known \\
\hline
\end{tabular}



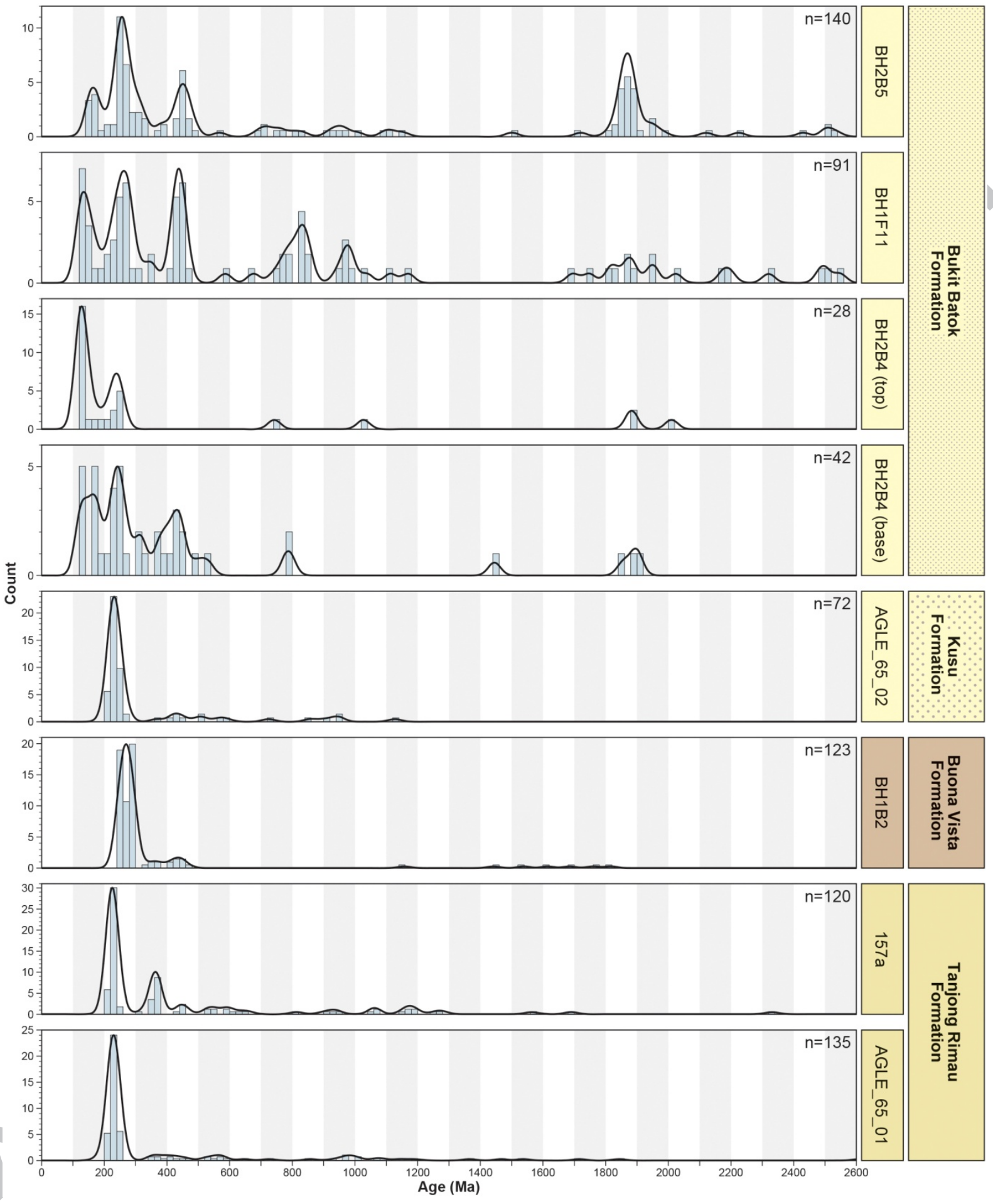


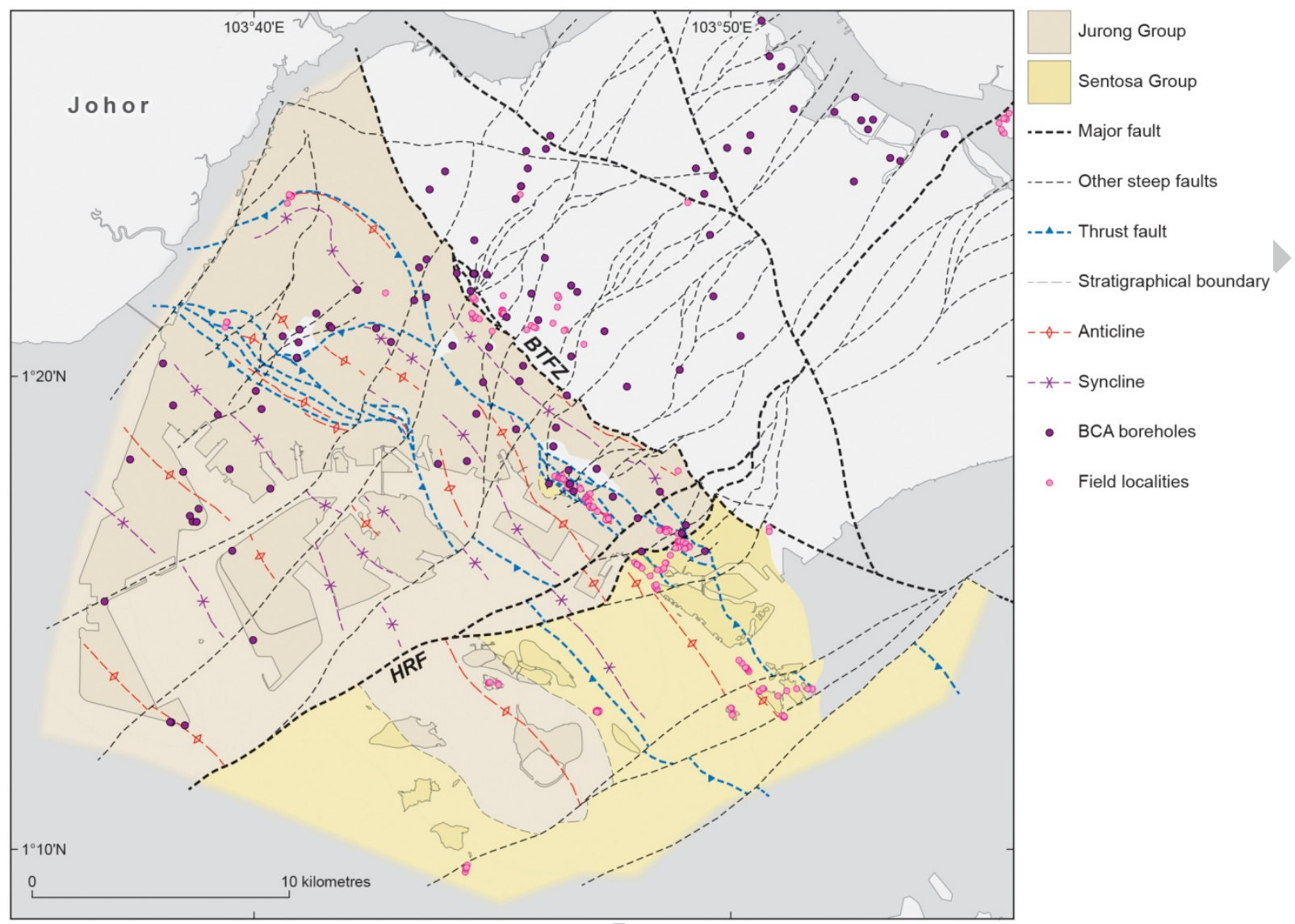




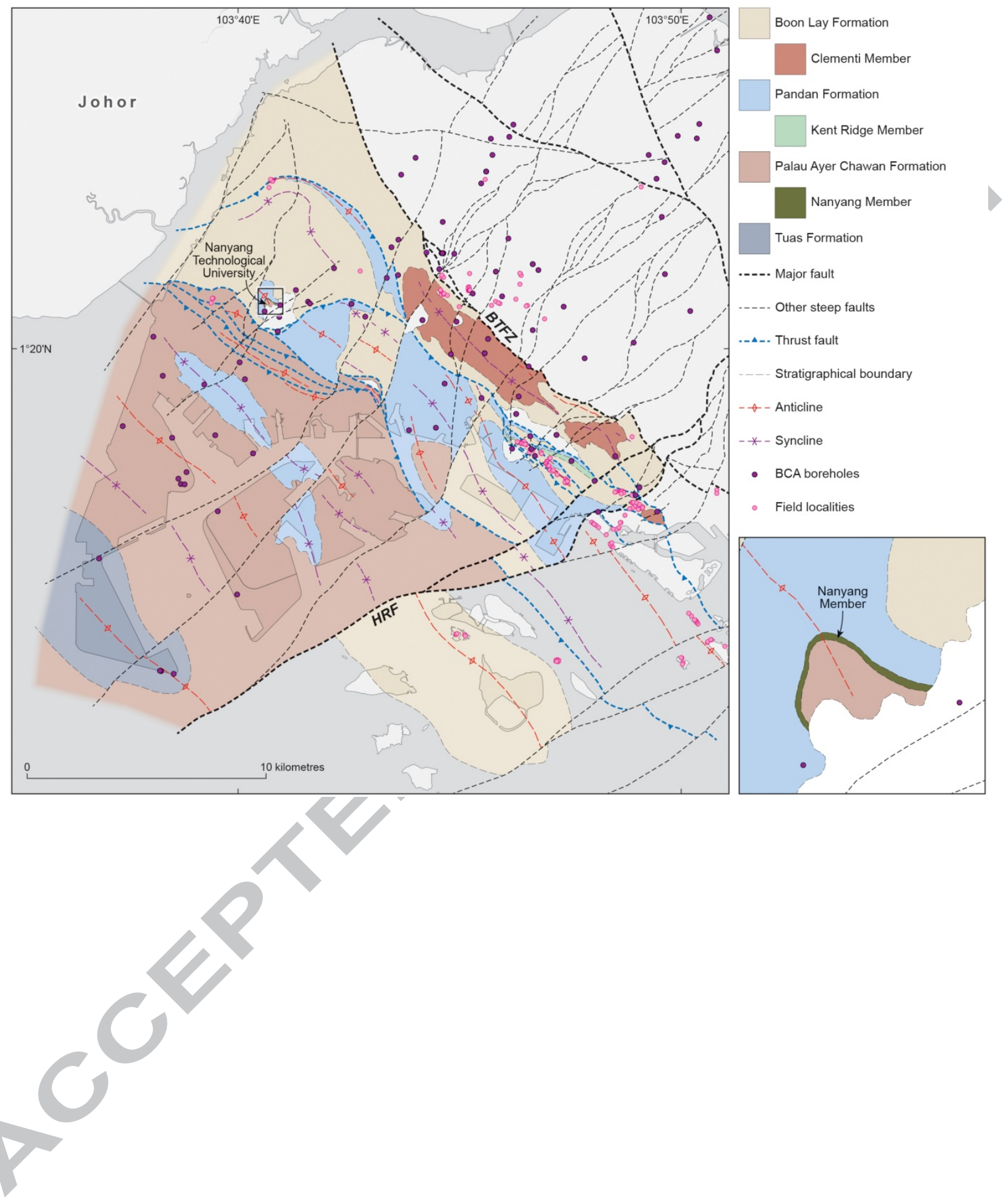



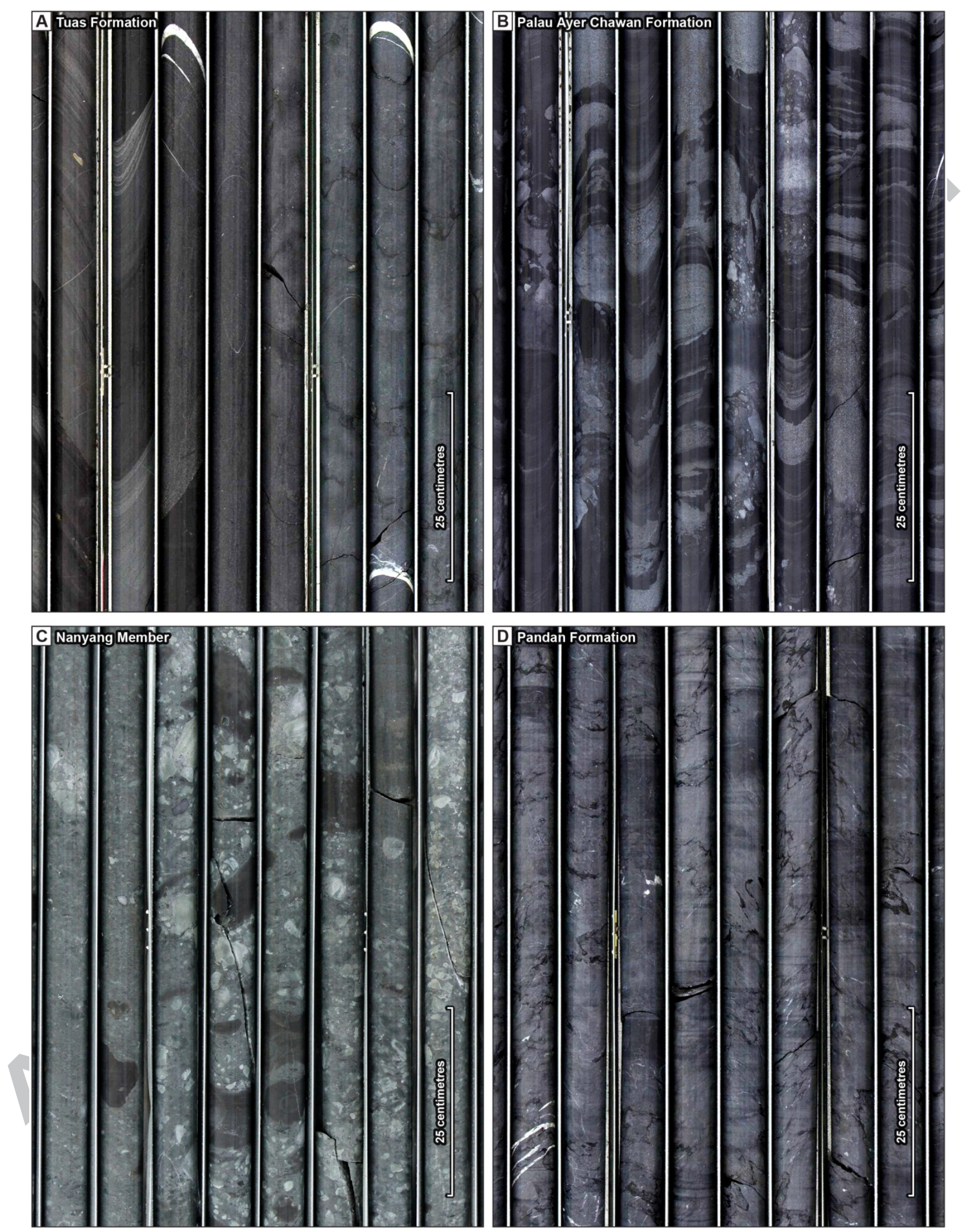

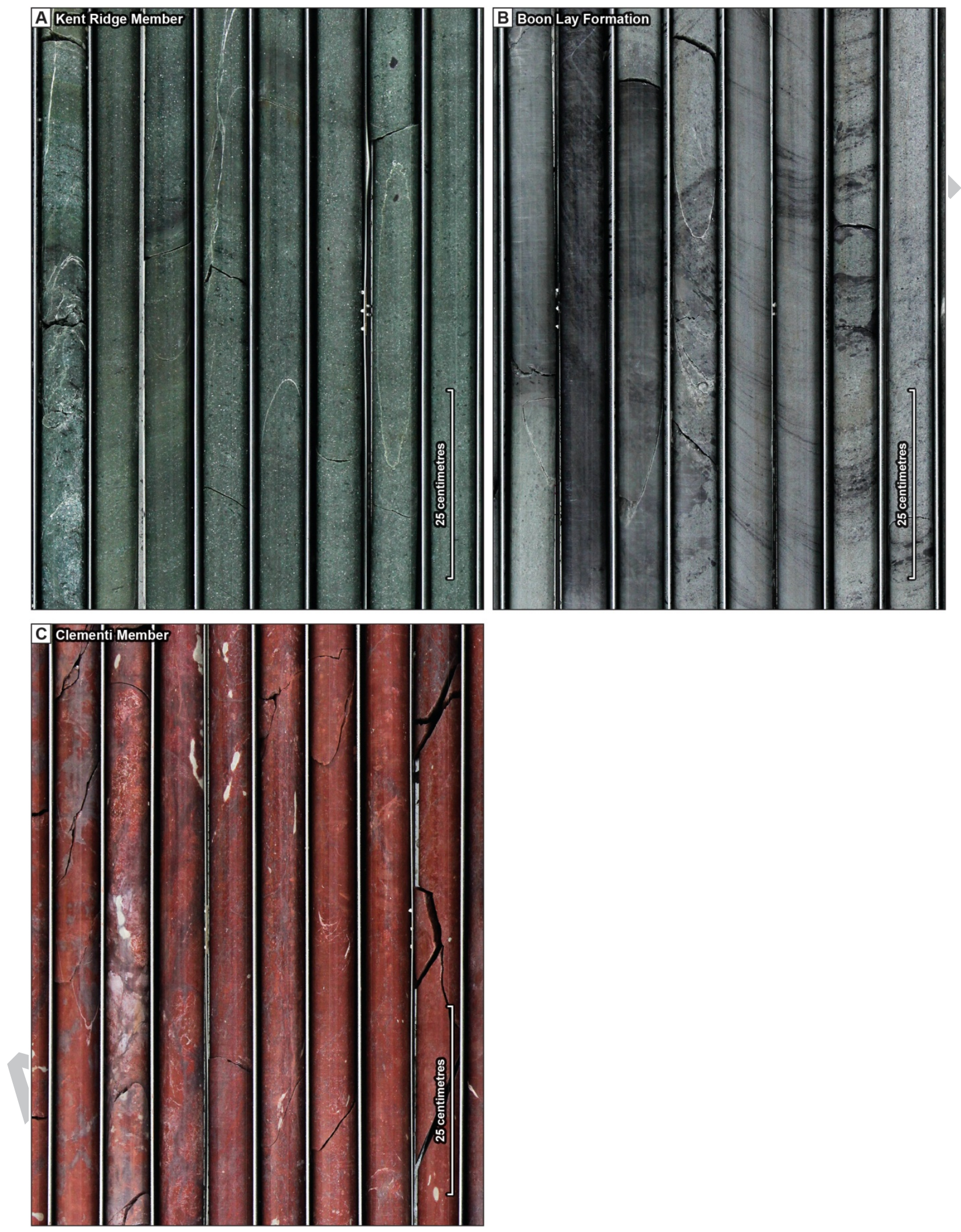

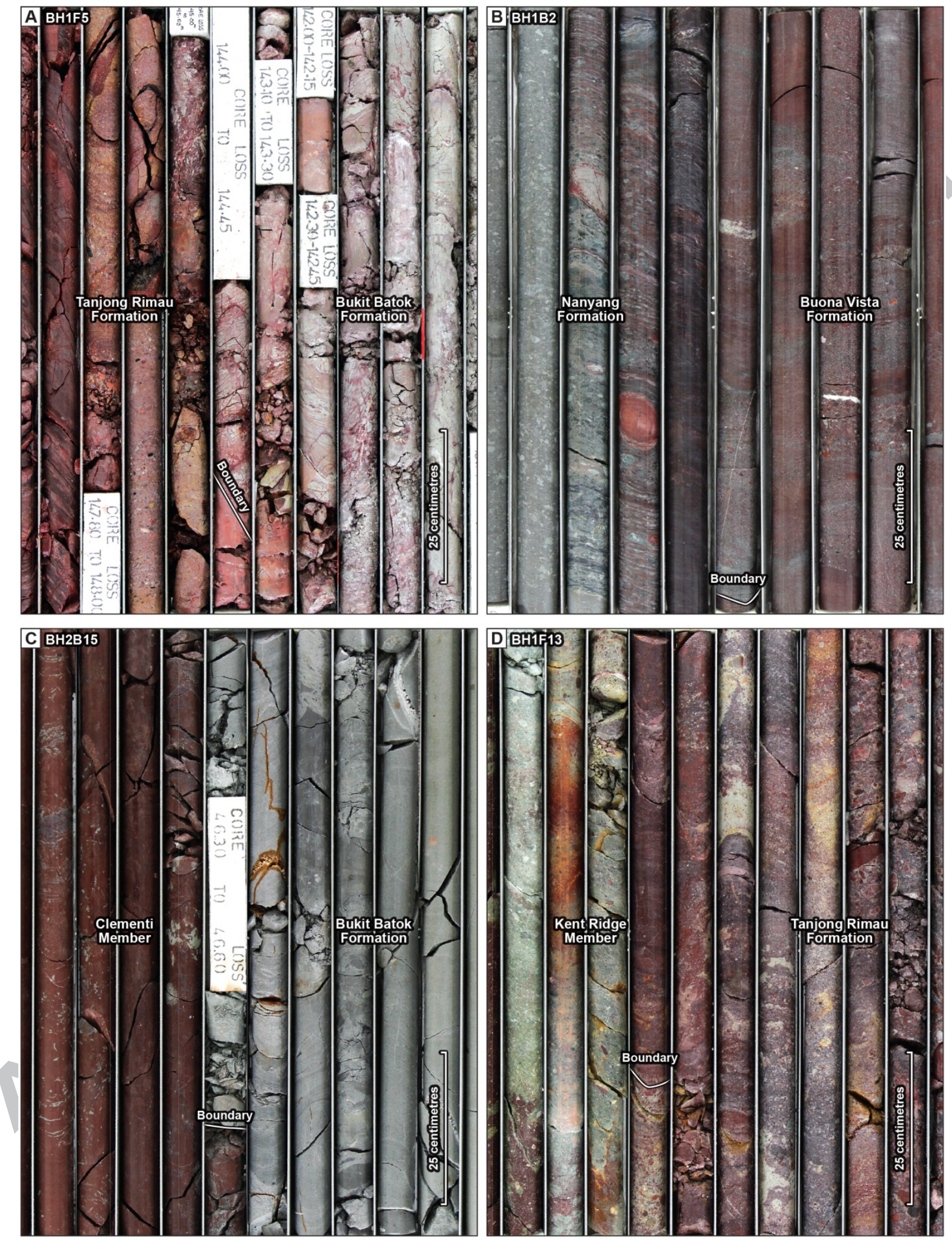


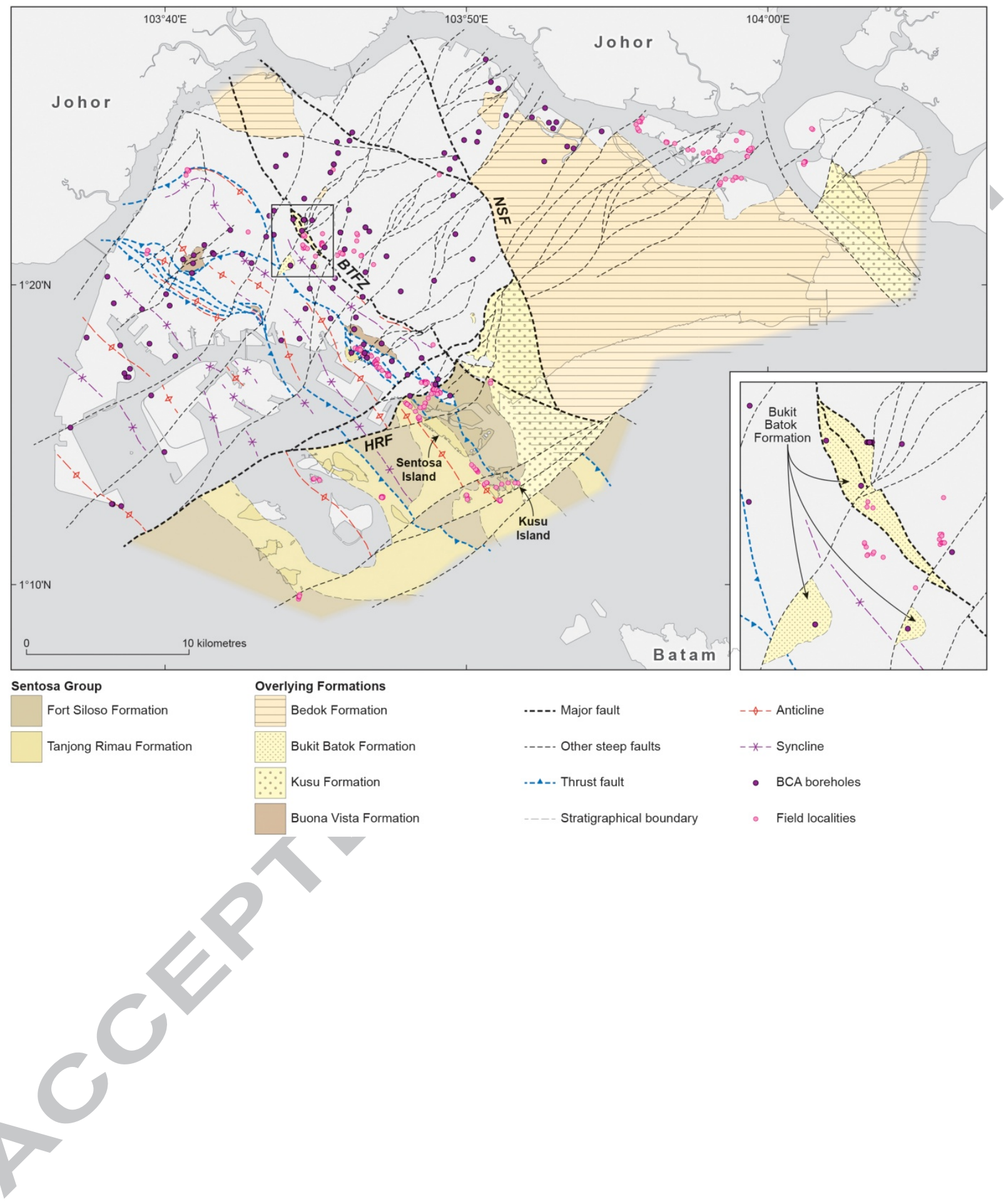



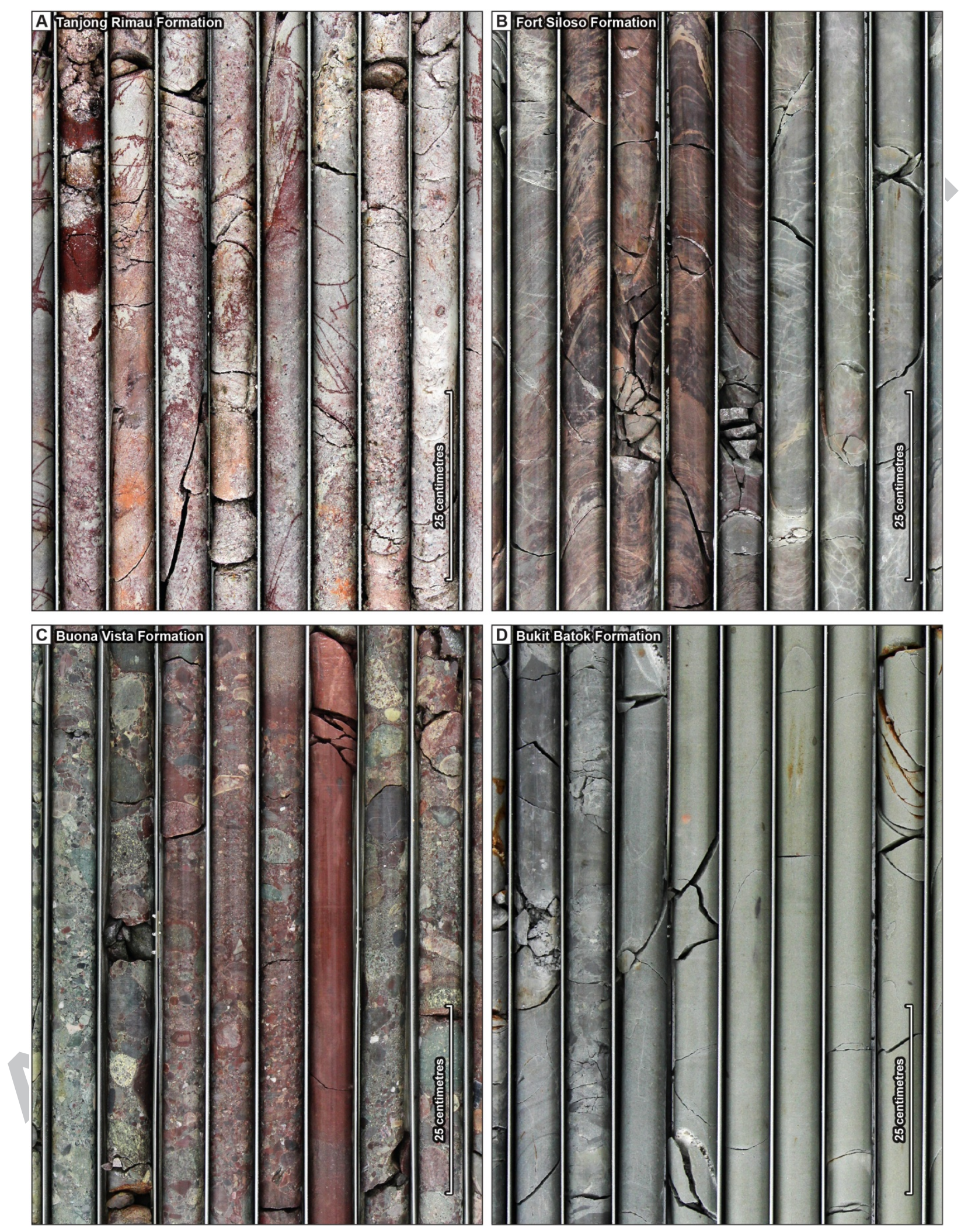

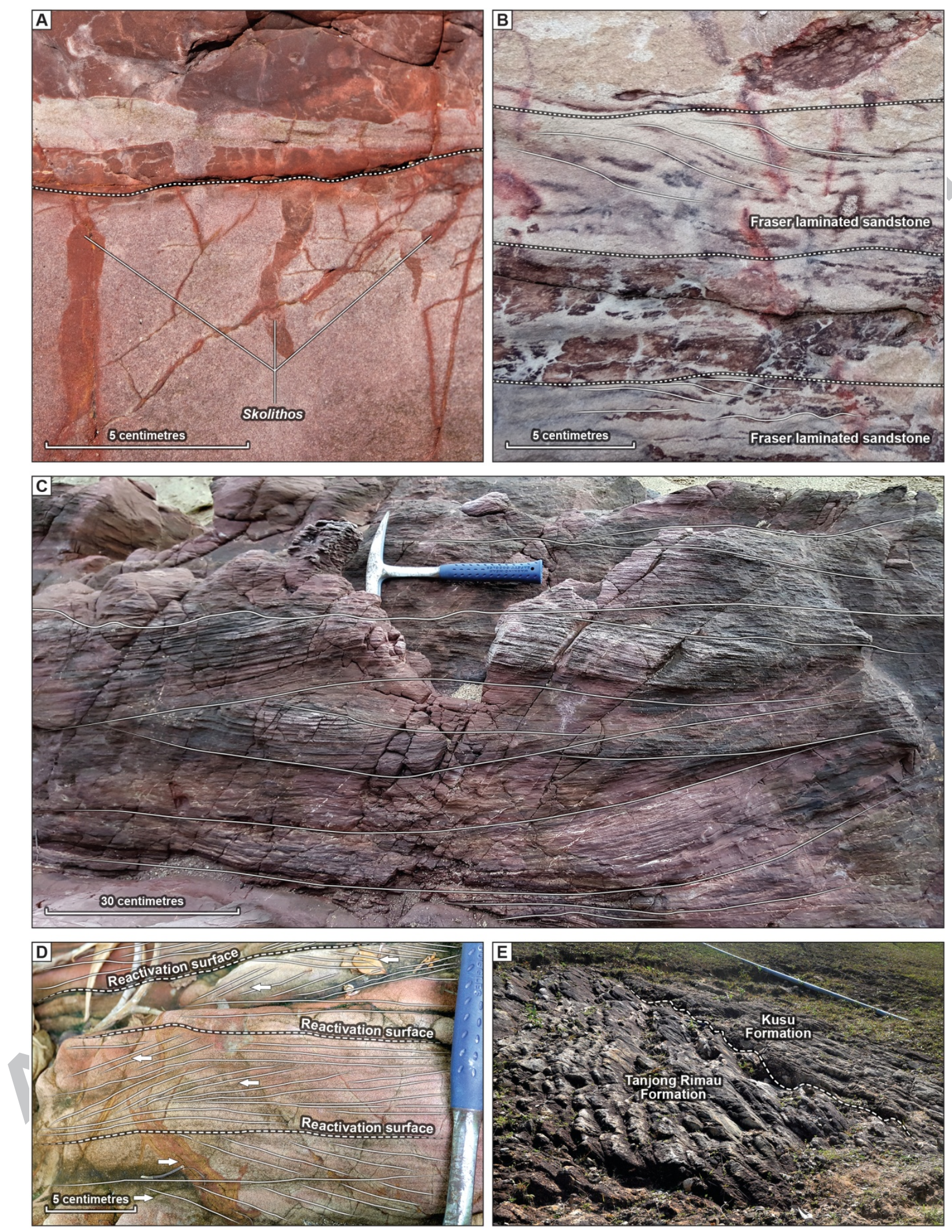

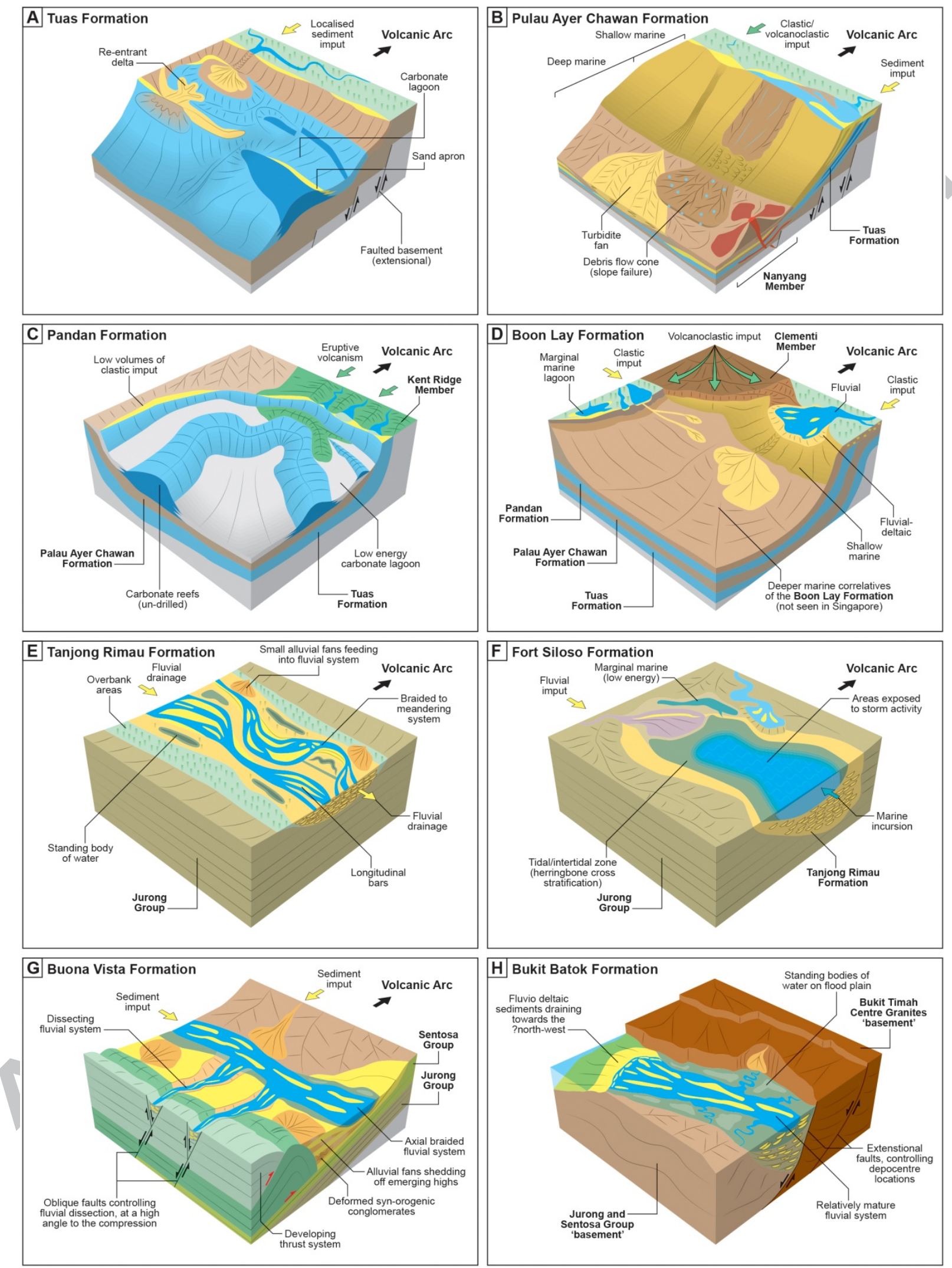


\begin{tabular}{|c|c|c|c|c|c|}
\hline $\begin{array}{l}\text { Unit } \\
\text { Name } \\
\end{array}$ & Stratotype (s) & Diagnostic Features & Justification for Stratal Position & $\begin{array}{ll}\text { Estimated } & \text { Maximum } \\
\text { Thickness } & \\
\end{array}$ & Borehole Data Sources \\
\hline $\begin{array}{l}\text { Bukit } \\
\text { Batok } \\
\text { Formation }\end{array}$ & $\begin{array}{l}\text { BH1F5 (10.5- } \\
144.80 \mathrm{~m})\end{array}$ & $\begin{array}{l}\text { Sandstones are fine- to medium- } \\
\text { grained and well- to very-well } \\
\text { sorted. Mudstones are dark grey to } \\
\text { black and rich in organic matter and } \\
\text { may show evidence of liquefaction. } \\
\text { The rock lacks the recrystallisation } \\
\text { and penetrative fabric that would be } \\
\text { associated with deformation and } \\
\text { metamorphism. }\end{array}$ & $\begin{array}{l}\text { The lower boundary separating the Bukit } \\
\text { Batok Formation from the underlying } \\
\text { Tanjong Rimau Formation is observed in } \\
\text { BH1F5 at } 144.80 \mathrm{~m} \text { (Fig. 9A). The formation } \\
\text { does not display the same degree of } \\
\text { deformation as the Jurong and Sentosa } \\
\text { Groups. The upper boundary is not observed } \\
\text { in core or at outcrop but is probably } \\
\text { unconformable with any overlying Cenozoic } \\
\text { units. }\end{array}$ & $\begin{array}{l}\text { Not measured directly. A } \\
\text { maximum thickness is } \\
\text { probably several } \\
\text { hundred metres based } \\
\text { on the thickest } \\
\text { intersection in core at } \\
194 \mathrm{~m} \text { (in BH2B5). }\end{array}$ & $\begin{array}{lr}\text { BH2B4 } & (24.10-205.00 \mathrm{~m}) ; \\
\text { BH2B5 } & (11.00-205.00 \mathrm{~m}) ; \\
\text { BH2B13 } & (12.60-205.00 \mathrm{~m}) ; \\
\text { BH2B15 } & (15.00-46.80 \mathrm{~m}) ; \\
\text { BH1F5 } & (10.50-144.80 \mathrm{~m}) ; \\
\text { BH1F11 } & (27.50-205.00 \mathrm{~m}) ; \\
\text { BH1F11a } & (28.20-29.20 \mathrm{~m}) .\end{array}$ \\
\hline $\begin{array}{l}\text { Kusu } \\
\text { Formation }\end{array}$ & $\begin{array}{l}\text { Kusu Island is } \\
\text { the stratotype } \\
\text { for the Kusu } \\
\text { Formation in } \\
\text { Singapore }\end{array}$ & $\begin{array}{l}\text { Quartz-rich, thickly-bedded } \\
\text { sandstone comprised of rounded to } \\
\text { very well rounded, medium- to } \\
\text { coarse-grained quartz grains with } \\
\text { well-developed quartz overgrowths. } \\
\text { The rock lacks the recrystallisation } \\
\text { and penetrative fabric that would be } \\
\text { associated with deformation and } \\
\text { metamorphism. }\end{array}$ & $\begin{array}{l}\text { The lower boundary is an unconformity } \\
\text { between the Kusu Formation and all older } \\
\text { units exposed at Telok Blangah Park. The age } \\
\text { of the formation is determined as Lower } \\
\text { Cretaceous, based on a } \leq 156 \pm 1 \text { Ma date } \\
\text { from Kusu Island, and a younger date of } \\
\leq 145 \pm 1 \mathrm{Ma} \text { from a boulder of Kusu } \\
\text { Formation in the Fort Canning Boulder Bed } \\
\text { (Oliver and Gupta, 2019). On both accounts, } \\
\text { the Kusu Formation is considerably younger } \\
\text { than the underlying Triassic successions (c. } \\
245-215 \mathrm{Ma} \text { ). Furthermore, the formation } \\
\text { does not display the same degree of } \\
\text { deformation, with no evidence for a } \\
\text { penetrative cleavage. The upper formation } \\
\text { boundary corresponds with the present-day } \\
\text { erosion surface. }\end{array}$ & $\begin{array}{l}\text { Not measured directly. A } \\
\text { maximum thickness in } \\
\text { Singapore is at least } \\
400 \mathrm{~m} \text {, based on the } \\
\text { national 3D geological } \\
\text { model. }\end{array}$ & None \\
\hline $\begin{array}{l}\text { Buona } \\
\text { Vista } \\
\text { Formation }\end{array}$ & $\begin{array}{l}\text { BH2B8 } \\
(144.6- \\
205.0 \mathrm{~m})\end{array}$ & $\begin{array}{l}\text { Conglomerate beds characterised by } \\
\text { rounded, cobble-grade clasts. These } \\
\text { beds are distinctive, and lack the } \\
\text { clast assemblage of conspicuous } \\
\text { white vein quartz, volcanic rocks, } \\
\text { extra-formational siliciclastic rocks, } \\
\text { and metamorphic rocks that } \\
\text { characterises the Tanjong Rimau } \\
\text { Formation. }\end{array}$ & $\begin{array}{l}\text { The lower formation boundary between the } \\
\text { Buona Vista Formation and the Nanyang } \\
\text { Member of the Pulau Ayer Chawan } \\
\text { Formation is observed in core data from } \\
\text { BH1B1 and BH1B2 (Fig. 9B). The lower } \\
\text { boundary is characterised as structural, with } \\
\text { intense ductile deformation and mylonitic } \\
\text { rock. The upper boundary is not observed in } \\
\text { core or outcrop, but the difference in likely } \\
\text { ages of the Buona Vista Formation (between } \\
245 \text { and } 198 \mathrm{Ma} \text { ) and the overlying Bukit } \\
\text { Batok Formation ( }(<123 \mathrm{Ma} \text { ) suggests the } \\
\text { latter is significantly younger. }\end{array}$ & $\begin{array}{l}\text { Not measured directly. } \\
\text { Its minimum thickness is } \\
\text { likely to be at least } \\
\text { several hundred metres, } \\
\text { based on the thickest } \\
\text { intersection in core at } \\
179 \mathrm{~m} \text { (in BH2F4). }\end{array}$ & $\begin{array}{lr}\text { BH1B1 } & (27.05-114.40 \mathrm{~m}) ; \\
\text { BH1B2 } & (32.60-62.99 \mathrm{~m}) ; \\
\text { BH2B8 } & (144.60-205.00 \mathrm{~m}) ; \\
\text { BH1F8 } & (35.00-104.00 \mathrm{~m}) ; \\
\text { BH1F8a } & (34.00-110.80 \mathrm{~m}) ; \\
\text { BH2F4 } & (25.80-205.00 \mathrm{~m}) ; \\
\text { BH2F4a } & (25.80-36.00 \mathrm{~m}) .\end{array}$ \\
\hline $\begin{array}{l}\text { Fort Siloso } \\
\text { Formation }\end{array}$ & $\begin{array}{l}\text { A coastal } \\
\text { section on the } \\
\text { north-west } \\
\text { corner of } \\
\text { Sentosa Island } \\
\text { is the } \\
\text { stratotype for } \\
\text { the Fort Siloso } \\
\text { Formation. }\end{array}$ & $\begin{array}{l}\text { Composed dominantly of clay- to } \\
\text { silt-grade, siliciclastic mudstones } \\
\text { interbedded with very-fine- to fine- } \\
\text { grained, very well sorted, very } \\
\text { mature sandstones with sub-angular } \\
\text { sand grains. }\end{array}$ & $\begin{array}{l}\text { The lower boundary between the Fort Siloso } \\
\text { Formation and the underlying Tanjong Rimau } \\
\text { Formation is observed in outcrop at the } \\
\text { north-west corner of Sentosa Island, where } \\
\text { the succession is the right way-up. The upper } \\
\text { boundary between the Fort Siloso Formation } \\
\text { and younger formations is not observed in } \\
\text { outcrop or in borehole data. The significant } \\
\text { time gap between deposition of the Fort } \\
\text { Siloso Formation and the overlying Kusu and } \\
\text { Bukit Batok formations (Fig. 3) indicates the } \\
\text { upper boundary is likely unconformable. }\end{array}$ & $\begin{array}{l}\text { Not measured directly. It } \\
\text { is known to be in excess } \\
\text { of } 190 \mathrm{~m} \text { based on the } \\
\text { thickest intersection of } \\
\text { Fort Siloso Formation } \\
\text { strata (in BH1F2). }\end{array}$ & BH1F2 (15.50-205.00 m). \\
\hline $\begin{array}{l}\text { Tanjong } \\
\text { Rimau } \\
\text { Formation }\end{array}$ & $\begin{array}{l}\text { The coastal } \\
\text { section in the } \\
\text { north-west } \\
\text { part of } \\
\text { Sentosa Island } \\
\text { (Tanjong } \\
\text { Rimau) }\end{array}$ & $\begin{array}{l}\text { 1-30 metre-thick packages of fine- } \\
\text { to very-coarse-grained, poorly } \\
\text { sorted, angular to sub-angular, } \\
\text { quartz-rich sandstones, and 1-4 } \\
\text { metre-thick mudstones thinly } \\
\text { interbedded with very-fine- to } \\
\text { medium-grained, well-sorted } \\
\text { sandstones. Conglomerate beds } \\
\text { have a distinctive clast assemblage } \\
\text { that includes conspicuous white vein } \\
\text { quartz, volcanic rocks, extra- } \\
\text { formational siliciclastic rocks, and } \\
\text { metamorphic rocks, and lack the } \\
\text { rounded, cobble to boulder-grade } \\
\text { clasts that characterise the Buona } \\
\text { Vista Formation. }\end{array}$ & $\begin{array}{l}\text { The lower boundary between the Tanjong } \\
\text { Rimau Formation and the underlying Pandan } \\
\text { Formation is observed in BH1F13 and is } \\
\text { unconformable. This relationship suggests } \\
\text { the sediments of the Sentosa Group, of } \\
\text { which the Tanjong Rimau Formation forms } \\
\text { the lowest unit, rests unconformably on the } \\
\text { Jurong Group. The upper boundary between } \\
\text { the Tanjong Rimau Formation and the } \\
\text { overlying Fort Siloso Formation is observed } \\
\text { in outcrop on Sentosa Island. }\end{array}$ & $\begin{array}{l}\text { Not measured directly. It } \\
\text { is at least } 165 \mathrm{~m} \text { as } \\
\text { observed in BH1F6; a } \\
\text { much greater maximum } \\
\text { thickness of } 1,000- \\
2,000 \mathrm{~m} \text { is possible } \\
\text { based on outcrop maps, } \\
\text { average dip, and the 3D } \\
\text { geological model of } \\
\text { Singapore. }\end{array}$ & $\begin{array}{lr}\text { BH1F5 } & (144.80-201.00 \mathrm{~m}) \\
\text { BH1F6 } & (36.00-201.00 \mathrm{~m}) \text {; } \\
\text { BH1F13 } & (8.90-89.80 \mathrm{~m}) ; \\
\text { BH2F9 } & (2.30-56.55 \mathrm{~m}) .\end{array}$ \\
\hline $\begin{array}{l}\text { Pengerang } \\
\text { Formation }\end{array}$ & $\begin{array}{l}\text { None in } \\
\text { Singapore - } \\
\text { Pengerang } \\
\text { area of Johor, } \\
\text { in Malaysia }\end{array}$ & $\begin{array}{l}\text { The dominant lithology is pyroclastic } \\
\text { rock, probably primarily lapilli-tuff } \\
\text { and tuff. Embedded rock fragments } \\
\text { are usually less than } 50 \mathrm{~mm} \text { in } \\
\text { diameter suggesting that the } \\
\text { lithology is generally lapilli-tuff. } \\
\text { A thin section of Pengerang } \\
\text { Formation rock from an unidentified } \\
\text { location in Singapore consisted of } \\
\text { "lithic tuff with andesitic fragments } \\
\text { set in a groundmass of irregular } \\
\text { feldspar laths, glass, and opaque } \\
\text { ore" (DSTA, 2009) }\end{array}$ & $\begin{array}{l}\text { Both the lower and upper boundaries of the } \\
\text { Pengerang Formation were not observed in } \\
\text { core data, or in outcrop. The Pengerang } \\
\text { Formation has been placed in the } \\
\text { stratigraphy on the basis of it being the } \\
\text { product of a pyroclastic flow and it being } \\
\text { time-equivalent with the Clementi Member } \\
\text { of the Boon Lay Formation. It not thought to } \\
\text { be part of the same Semantan Basin fill as } \\
\text { the rest of the succession in Singapore. }\end{array}$ & $\begin{array}{l}\text { Unknown. } \begin{array}{r}\text { Current } \\
\text { information is }\end{array} \\
\text { insufficient to place a } \\
\text { meaningful constraint } \\
\text { on the maximum } \\
\text { thickness of this unit in } \\
\text { Singapore; modern-day } \\
\text { reef outcrops exposed in } \\
\text { Selat Johor between } \\
\text { Pulau Tekong and the } \\
\text { Pengerang area of Johor } \\
\text { (Fig. 2) indicate a } \\
\text { thickness of at least a } \\
\text { few tens of metres. }\end{array}$ & None \\
\hline $\begin{array}{l}\text { Clementi } \\
\text { Member }\end{array}$ & $\begin{array}{l}\text { BH2B15 } \\
(46.80-\end{array}$ & $\begin{array}{l}\text { The unit consists mainly of reddened } \\
\text { palaeosol, typically Andisol and }\end{array}$ & $\begin{array}{l}\text { The lower boundary between the Clementi } \\
\text { Member and the Boon Lay Formation is }\end{array}$ & $\begin{array}{l}\text { Not measured directly. A } \\
\text { maximum thickness in }\end{array}$ & $\begin{array}{ll}\text { BH2B15 } & (46.80-179.30 \mathrm{~m}) ; \\
\text { BH1F1 } & (45.10-205.60 \mathrm{~m}) ; \\
\end{array}$ \\
\hline
\end{tabular}




\begin{tabular}{|c|c|c|c|c|c|}
\hline & $179.30 \mathrm{~m})$ & $\begin{array}{l}\text { Ultisol in beds } 5-20 \text { metres thick } \\
\text { interbedded with unreddened fine } \\
\text { to medium grained sandstones The } \\
\text { reddened palaeosols are also found } \\
\text { in the Boon Lay, Fort Siloso and } \\
\text { Bukit Batok formations, but in those } \\
\text { units the reddened intervals } \\
\text { typically are } 1-5 \text { metres thick. The } \\
\text { alteration associated with palaeosol } \\
\text { development produces strong } \\
\text { colours, which are diagnostic. In } \\
\text { terms of the Munsell colour system, } \\
\text { the colours range from 'weak red' } \\
\text { (10R } 5 / 4) \text { or 'reddish brown' ( } 2.5 Y R \\
5 / 4) \text { to 'reddish gray' ( } 2.5 Y R / 10 R \\
5 / 1) \text {. Coarse-grained sedimentary } \\
\text { rock (e.g. conglomerate) is absent. }\end{array}$ & $\begin{array}{l}\text { observed in core data from BH2B15. } \\
\text { However, the Clementi Member } \\
\text { interdigitates with the Boon Lay Formation, } \\
\text { and the two units can alternate within a } \\
\text { single core. The upper boundary between } \\
\text { the Clementi Member and the overlying } \\
\text { Bukit Batok Formation is observed in core } \\
\text { data from BH2B15 (Fig. 9C), where it is } \\
\text { unconformable. }\end{array}$ & $\begin{array}{l}\text { excess of several } \\
\text { hundred metres is likely, } \\
\text { based on the thickest } \\
\text { intersection recorded in } \\
\text { core at } 160 \mathrm{~m} \text { (in } \\
\text { BH1F1). }\end{array}$ & $\begin{array}{lr}\text { BH1F3 } & (7.00-205.00 \mathrm{~m})^{*} ; \\
\text { BH1F4 } & (24.07-133.7 \mathrm{~m}) ; \\
\text { BH1F10 } & (19.00-113.50 \mathrm{~m}) ; \\
\text { BH1F12 } & (7.00-86.40 \mathrm{~m}) \text {; } \\
\text { BH2F5 } & (103.50-205.00 \mathrm{~m}) ; \\
\text { BH2F6 } & (33.00-107.30 \mathrm{~m}) .{ }^{*} \\
\text { The unit interdigitates with } \\
\text { the Boon Lay Formation in } \\
\text { this borehole }\end{array}$ \\
\hline $\begin{array}{l}\text { Boon Lay } \\
\text { Formation }\end{array}$ & $\begin{array}{l}\text { BH2B10 } \\
(32.10- \\
188.71 \mathrm{~m})\end{array}$ & $\begin{array}{l}\text { Sandstone are dominant, typically } \\
\text { laminated, very fine- to medium- } \\
\text { grained, with clay rich laminae. } \\
\text { Common mud drapes on } \\
\text { sedimentary structures in the } \\
\text { sandstone ('flaser lamination'). } \\
\text { Sandstone packages commonly } \\
\text { coarsen upwards and have } \\
\text { interbedded, thin layers of } \\
\text { mudstone. Thin (1-3 metre thick) } \\
\text { units of micritic limestone are } \\
\text { developed occasionally. }\end{array}$ & $\begin{array}{l}\text { The lower boundary between the Boon Lay } \\
\text { Formation and the underlying Pandan } \\
\text { Formation is observed in core data from } \\
\text { BH1F7 and BH2B10. The upper boundary } \\
\text { between the Boon Lay Formation and the } \\
\text { overlying Tanjong Rimau Formation is } \\
\text { observed in core data in BH2F9 (at } 56 \mathrm{~m} \text { ). }\end{array}$ & $\begin{array}{l}\text { Not measured directly. A } \\
\text { maximum thickness of } \\
\text { several hundred metres } \\
\text { is likely based on the } \\
\text { thickest intersection in } \\
\text { core at } 155 \mathrm{~m} \text { (in } \\
\text { BH2B15). }\end{array}$ & $\begin{array}{lr}\text { BH1B3 } & (71.00-201.00 \mathrm{~m}) ; \\
\text { BH1B5 } & (43.04-205.00 \mathrm{~m}) ; \\
\text { BH1B7 } & (24.00-204.00 \mathrm{~m}) ; \\
\text { BH2B8 } & (17.00-144.60 \mathrm{~m}) ; \\
\text { BH2B10 } & (32.10-188.71 \mathrm{~m}) ; \\
\text { BH2B12 } & (33.50-180.00 \mathrm{~m}) ; \\
\text { BH2B14 } & (4.00-33.00 \mathrm{~m}) ; \\
\text { BH2B14a } & (18.00-58.00 \mathrm{~m}) ; \\
\text { BH2B15 } & (179.30-205.00 \mathrm{~m}) ; \\
\text { BH1F4 } & (133.70-205.00 \mathrm{~m}) ; \\
\text { BH1F7 } & (15.80-44.10 \mathrm{~m}) ; \\
\text { BH1F8 } & (104.15-117.00 \mathrm{~m}) ; \\
\text { BH1F8A } & (110.80-205.00 \mathrm{~m}) ; \\
\text { BH1F10 } & (113.50-205.00 \mathrm{~m}) ; \\
\text { BH2F3 } & (23.67-201.00 \mathrm{~m}) ; \\
\text { BH2F6 } & (107.30-205.00 \mathrm{~m}) ; \\
\text { BH2F9 }(56.55-205.00 \mathrm{~m}) .\end{array}$ \\
\hline $\begin{array}{l}\text { Kent } \\
\text { Ridge } \\
\text { Member }\end{array}$ & $\begin{array}{l}\text { BH1F9 } \\
(17.20- \\
205.00 \mathrm{~m})\end{array}$ & $\begin{array}{l}\text { The rock consists almost entirely of } \\
\text { structureless lapilli-tuff, with } \\
\text { significant proportions of fiamme, } \\
\text { lithic fragments and crystals in an } \\
\text { ash-grade matrix. Most fiamme are } \\
\text { green, less than } 50 \mathrm{~mm} \text { long, } \\
\text { moderately flattened (aspect ratios } \\
<8: 1 \text { ) and aligned. Most lithic clasts } \\
\text { are less than } 30 \mathrm{~mm} \text { in size and } \\
\text { formed of porphyritic volcanic rock; } \\
\text { entrained crystals up to } 4 \mathrm{~mm} \text { in } \\
\text { diameter consist of quartz and } \\
\text { feldspar. }\end{array}$ & $\begin{array}{l}\text { The lower boundary between the Kent Ridge } \\
\text { Member and the Pandan Formation is } \\
\text { observed in BH1B6 is sharp and } \\
\text { conformable. The upper boundary between } \\
\text { the Kent Ridge Member of the Pandan } \\
\text { Formation and the Tanjong Rimau Formation } \\
\text { of the Sentosa Group is observed in BH1F13 } \\
\text { (Fig. 9D), where it is unconformable. This } \\
\text { relationship proves that, in some location, } \\
\text { the Sentosa Group is erosive and } \\
\text { unconformable on the Jurong Group. }\end{array}$ & $\begin{array}{l}\text { Not measured directly. A } \\
\text { maximum thickness is } \\
\text { likely in excess of } 200 \mathrm{~m} \text {, } \\
\text { based upon the thickest } \\
\text { section recorded in core } \\
\text { at } 188 \mathrm{~m} \text { (in BH1F9) }\end{array}$ & $\begin{array}{ll}\text { BH1B6 } & (74.00-206.00 \mathrm{~m}) ; \\
\text { BH1F9 } & (17.20-205.00 \mathrm{~m}) ; \\
\text { BH1F13 } & (89.80-205.00 \mathrm{~m}) ; \\
\text { BH2F8 } & (16.50-205.00 \mathrm{~m}) ; \\
\text { BH2F8A } & (16.50-21.20 \mathrm{~m}) .\end{array}$ \\
\hline $\begin{array}{l}\text { Pandan } \\
\text { Formation }\end{array}$ & $\begin{array}{l}\text { BH1A8 } \\
(16.15- \\
138.17 \mathrm{~m})\end{array}$ & $\begin{array}{l}\text { Thickly bedded, homogenous } \\
\text { micritic limestone in intervals } 5-50 \\
\text { metres thick; a general lack of } \\
\text { carbonate allochems (including } \\
\text { peloids and oncoids), though these } \\
\text { do occur in places. Occasional } \\
\text { isolated, thinly and thickly bedded } \\
\text { layers of tuff and tuffite. Rare, } \\
\text { interbedded layers of sandstone and } \\
\text { mudstone. }\end{array}$ & $\begin{array}{l}\text { The lower boundary between the Pandan } \\
\text { Formation and the Pulau Ayer Chawan } \\
\text { Formation is observed in BH1A8 and BH2B7. } \\
\text { The upper boundary between the Pandan } \\
\text { Formation and the overlying Boon Lay } \\
\text { Formation is observed in core data in BH1F7 } \\
\text { and BH2B10. }\end{array}$ & $\begin{array}{l}\text { Not measured directly. A } \\
\text { maximum thickness in } \\
\text { excess of several } \\
\text { hundred metres is likely } \\
\text { based on the thickest } \\
\text { intersection in core } \\
\text { recorded at } 181 \mathrm{~m} \text { (in } \\
\text { BH2F7). }\end{array}$ & $\begin{array}{lr}\text { BH1A8 } & (16.15-138.17 \mathrm{~m}) ; \\
\text { BH1B4 } & (54.00-113.00 \mathrm{~m}) ; \\
\text { BH1B4a } & (53.00-206.00 \mathrm{~m}) ; \\
\text { BH1B6 } & (17.50-74.40 \mathrm{~m}) ; \\
\text { BH2B7 } & (54.15-60.44 \mathrm{~m}) ; \\
\text { BH2B10 } & (188.71-200.53 \mathrm{~m}) ; \\
\text { BH1F7 } & (44.10-205.00 \mathrm{~m}) ; \\
\text { BH2F1 } & (70.10-153.00 \mathrm{~m}) ; \\
\text { BH2F2 } & (20.50-201.00 \mathrm{~m}) ; \\
\text { BH2F7 }(19.80-201.00 \mathrm{~m}) . \\
\end{array}$ \\
\hline $\begin{array}{l}\text { Nanyang } \\
\text { Member }\end{array}$ & $\begin{array}{l}\text { BH1B2 } \\
(62.99- \\
118.90 \mathrm{~m})\end{array}$ & $\begin{array}{l}\text { The rock is clastic, and dominated by } \\
\text { clasts of one type (andesitic rock). } \\
\text { The igneous rock clasts typically } \\
\text { have polygonal shape and a } \\
\text { concentrically zoned character (dark } \\
\text { green rims and paler cores). } \\
\text { Pyroclastic rocks erupted sub- } \\
\text { aerially lack these features. Clasts of } \\
\text { dark grey mudstone and grey } \\
\text { limestone usually are present in } \\
\text { subordinate proportions. Metre- } \\
\text { scale, normally graded layers. }\end{array}$ & $\begin{array}{l}\text { The lower boundary between the Nanyang } \\
\text { Member and the Pulau Ayer Chawan } \\
\text { Formation is observed in BH1B1, BH1B2, } \\
\text { BH2B3, and BH2B7 where it is always } \\
\text { conformable, though in detail the two units } \\
\text { inter-digitate. The upper boundary between } \\
\text { the Nanyang Member and the overlying } \\
\text { Pandan Formation is observed in BH1A8 and } \\
\text { BH2B7. }\end{array}$ & $\begin{array}{l}\text { The maximum Nanyang } \\
\text { Member thickness } \\
\text { intersected in the gently } \\
\text { dipping strata in BH1B2 } \\
\text { is } 56 \mathrm{~m} \text {. The Nanyang } \\
\text { Member rocks are } \\
\text { unconformably overlain } \\
\text { by strata assigned to the } \\
\text { Buona Vista Formation } \\
\text { and a unknown } \\
\text { thickness of the } \\
\text { Nanyang Member will } \\
\text { have been eroded. }\end{array}$ & $\begin{array}{lc}\text { BH2A13 } & (147.50-170.30 \mathrm{~m}) ; \\
\text { BH1B1 } & (114.40-167.70 \mathrm{~m}) ; \\
\text { BH1B2 } & (62.99-118.95 \mathrm{~m}) ; \\
\text { BH2B3 } & (171.85-188.20 \mathrm{~m}) ; \\
\text { BH2B7 } & (60.44-104.55 \mathrm{~m}) .\end{array}$ \\
\hline $\begin{array}{l}\text { Pulau } \\
\text { Ayer } \\
\text { Chawan } \\
\text { Formation }\end{array}$ & $\begin{array}{l}\text { BH2A3 } \\
(39.00- \\
205.00 \mathrm{~m})\end{array}$ & $\begin{array}{l}\text { Interbeds of sandstone and } \\
\text { mudstone are on a centimetre to } \\
\text { metre-scale; layers of sandstone } \\
\text { typically are slightly muddy, } \\
\text { moderate to well-sorted, and } \\
\text { quartz-rich. Sand grains typically are } \\
\text { sub-angular to sub-rounded. } \\
\text { Intraformational mud-clasts are } \\
\text { common. Layers of mudstone } \\
\text { typically are dark grey to black, } \\
\text { laminated, and siliciclastic; Layers of } \\
\text { conglomerate (debris flow deposits) } \\
\text { typically are rich in clasts of } \\
\text { carbonate rock and granitic rock. Re- } \\
\text { worked volcanogenic material, } \\
\text { typically manifesting as layers of } \\
\text { greenish sandstone, tuffite and fine } \\
\text { tuff, is common. }\end{array}$ & $\begin{array}{l}\text { The boundary between the Pulau Ayer } \\
\text { Chawan Formation and the underlying Tuas } \\
\text { Formation is intersected and observed in } \\
\text { BH2A12, where the succession is overturned } \\
\text { and beds are the wrong way up, but the } \\
\text { boundary between the two formations } \\
\text { appears to be sharp and conformable. The } \\
\text { upper boundary between the Pulau Ayer } \\
\text { Chawan Formation and the overlying Pandan } \\
\text { Formation is recorded in BH1A8 and BH2B7. }\end{array}$ & $\begin{array}{l}\text { Not measured directly. A } \\
\text { maximum thickness of } c \text {. } \\
2,000 \mathrm{~m} \text { based on } \\
\text { outcrop width, average } \\
\text { dip, and 3D geological } \\
\text { modelling (Leslie et al., } \\
\text { this issue). }\end{array}$ & $\begin{array}{lcc}\text { Cores: } & \text { BH1A4 } & (33.00- \\
205.03 \mathrm{~m}) ; & \text { BH1A5 } & (30.00- \\
200.00 \mathrm{~m}) ; & \text { BH1A6 } & (34.52- \\
205.00 \mathrm{~m}) ; & \text { BH1A8 } & (138.17- \\
205.00 \mathrm{~m}) ; & \text { BH1A9 } & (48.10- \\
205.00 \mathrm{~m}) ; & \text { BH1A10 } & (28.50- \\
205.00 \mathrm{~m}) ; & \text { BH1A11 } & (66.00- \\
205.00 \mathrm{~m}) ; & \text { BH2A2 } & (28.70- \\
205.00 \mathrm{~m}) ; & \text { BH2A3 } & (39.00- \\
205.00 \mathrm{~m}) ; & \text { BH2A4 } & (22.00- \\
205.00 \mathrm{~m}) ; & \text { BH2A5 } & (36.00- \\
201.00 \mathrm{~m}) ; & \text { BH2A8 } & (16.50- \\
205.00 \mathrm{~m}) ; & \text { BH2A12 } & (11.50- \\
179.00 \mathrm{~m}) ; & \text { BH2A13 } & (51.00- \\
147.50 \mathrm{~m} & \text { and } & 170.30- \\
205.00 \mathrm{~m}) ; & \text { BH1B1 } & (167.70- \\
205.00 \mathrm{~m}) ; & \text { BH1B2 } & (118.95- \\
205.00 \mathrm{~m}) ; & \text { BH2B3 } & (38.00- \\
171.85 \mathrm{~m} & \text { and } & 188.20- \\
205.00 \mathrm{~m}) ; & \text { BH2B7 } & (104.55- \\
201.00 \mathrm{~m}) . & & \\
201 & & \end{array}$ \\
\hline $\begin{array}{l}\text { Tuas } \\
\text { Formation }\end{array}$ & $\begin{array}{l}\text { BH1A1 } \\
(52.38- \\
205.00 \mathrm{~m})\end{array}$ & $\begin{array}{l}\text { Interbedded, cyclic successions of } \\
\text { typically } 10-15 \text { metre scale of } \\
\text { carbonate rock and siliciclastic rock. }\end{array}$ & $\begin{array}{l}\text { The lower boundary is not observed at } \\
\text { outcrop or in boreholes; defining features of } \\
\text { a boundary are not known. Although }\end{array}$ & $\begin{array}{l}\text { Not measured directly. A } \\
\text { maximum thickness of at } \\
\text { least several hundred }\end{array}$ & $\begin{array}{l}(52.38-205.00 \mathrm{~m}) ; \\
(42.08-205.00 \mathrm{~m}) ; \\
(47.20-155.00 \mathrm{~m}) ;\end{array}$ \\
\hline
\end{tabular}




\begin{tabular}{|c|c|c|c|c|c|}
\hline & & $\begin{array}{l}\text { Carbonate units typically } 1-20 \\
\text { metres thick, commonly with a } \\
\text { subordinate proportion of mudstone } \\
\text { forming irregular patches, and } \\
\text { commonly containing allochems } \\
\text { including oncoids and peloids. } \\
\text { Siliciclastic units typically } 1-20 \\
\text { metres thick; volcanogenic material } \\
\text { (tuff and tuffite) is rare. }\end{array}$ & $\begin{array}{l}\text { overturned, the upper boundary between } \\
\text { the Tuas Formations and the overlying Pulau } \\
\text { Ayer Chawan Formation is observed in } \\
\text { BH2A12 to be sharp and probably } \\
\text { conformable. }\end{array}$ & $\begin{array}{lr}\text { metres is implied by } \\
\text { continuous r Tuas } \\
\text { Formation successions } \\
\text { intersected in various } \\
\text { boreholes. }\end{array}$ & $\begin{array}{l}\text { BH2A1a } \quad(45.62-201.00 \mathrm{~m}) ; \\
\text { BH2A12 }(179.00-205.00 \mathrm{~m}) .\end{array}$ \\
\hline $\begin{array}{l}\text { Sajahat } \\
\text { Formation }\end{array}$ & Pulau Sajahat & $\begin{array}{l}\text { Glassy, grey, siliciclastic rock with a } \\
\text { faintly banded and metamorphosed } \\
\text { character. }\end{array}$ & $\begin{array}{l}\text { Neither upper or lower boundaries of this } \\
\text { formation have been observed at any } \\
\text { location. The formation is placed at the base } \\
\text { of the lithostratigraphy on the basis of age } \\
\text { determinations of metasandstone xenoliths } \\
\text { in the Choa Chu Kang pluton as a minimum } \\
\text { of } 285 \mathrm{Ma} \text { (see Gillespie et al., this issue), } \\
\text { and by Carboniferous aged zircons from } \\
\text { quartzites encountered in boreholes at } \\
\text { Punggol (Pan et al., 2018; Oliver and Gupta, } \\
\text { 2019). }\end{array}$ & $\begin{array}{l}\text { Not measured directly. A } \\
\text { maximum thickness is } \\
\text { likely to be at least 2- } \\
3000 \mathrm{~m} \text { based on } \\
\text { outcrop width and } \\
\text { average dip around } \\
\text { Pulau Sajahat and Pulau } \\
\text { Tekong. }\end{array}$ & 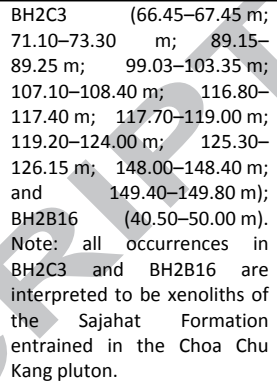 \\
\hline
\end{tabular}

\begin{tabular}{|c|c|c|c|}
\hline $\begin{array}{l}\text { Borehole } \\
\text { Name }\end{array}$ & $\begin{array}{l}\text { Location } \\
\text { (Northing, } \\
\text { Easting) }\end{array}$ & $\begin{array}{l}\text { Stratotype for } \\
\text { Unit: }\end{array}$ & Geological Significance \\
\hline BH1F5 & $\begin{array}{l}30873.75 \\
20935.59\end{array}$ & $\begin{array}{l}\text { Bukit Batok } \\
\text { Formation }\end{array}$ & $\begin{array}{l}\text { Contains deposits of the Tanjong Rimau Formation; } \\
\text { the overlying Bukit Batok Formation, and } \\
\text { documents the nature of the boundary between the } \\
\text { formations }\end{array}$ \\
\hline BH2B4 & $\begin{array}{l}31755.15 \\
17742.67\end{array}$ & None & Contains deposits of the Bukit Batok Formation \\
\hline BH2B8 & $\begin{array}{l}35776.69 \\
11121.99\end{array}$ & $\begin{array}{l}\text { Buona Vista } \\
\text { Formation }\end{array}$ & $\begin{array}{l}\text { Contains deposits of the Buona Vista Formation and } \\
\text { the Boon Lay Formation }\end{array}$ \\
\hline $\mathrm{BH} 2 \mathrm{~B} 15$ & $\begin{array}{l}36208.60 \\
18589.70\end{array}$ & $\begin{array}{l}\text { Clementi } \\
\text { Member }\end{array}$ & $\begin{array}{l}\text { Contains deposits of the Boon Lay Formation; } \\
\text { Clementi Member; and overlying Bukit Batok } \\
\text { Formation, and documents the nature of the } \\
\text { boundaries between these units }\end{array}$ \\
\hline BH2B10 & $\begin{array}{l}36399.80 \\
14781.34\end{array}$ & $\begin{array}{l}\text { Boon Lay } \\
\text { Formation }\end{array}$ & $\begin{array}{l}\text { Contains deposits of the Pandan Formation overlain } \\
\text { by the Boon Lay Formation, and documents the } \\
\text { nature of the boundary between the two formations }\end{array}$ \\
\hline BH1A8 & $\begin{array}{l}33556.64 \\
8056.08\end{array}$ & $\begin{array}{l}\text { Pandan } \\
\text { Formation }\end{array}$ & $\begin{array}{l}\text { Contains deposits of the Pulau Ayer Chawan } \\
\text { Formation overlain by the Pandan Formation, and } \\
\text { documents the nature of the boundary between the } \\
\text { two formations }\end{array}$ \\
\hline BH1B2 & $\begin{array}{l}36873.09 \\
11223.61\end{array}$ & $\begin{array}{l}\text { Nanyang } \\
\text { Member }\end{array}$ & $\begin{array}{l}\text { Contains deposits of the Pulau Ayer Chawan } \\
\text { Formation; Nanyang Member; and overlying Buona } \\
\text { Vista Formation, and documents the boundaries } \\
\text { between these units }\end{array}$ \\
\hline BH2A3 & $\begin{array}{l}28265.03 \\
8619.71\end{array}$ & $\begin{array}{l}\text { Pulau Ayer } \\
\text { Chawan } \\
\text { Formation }\end{array}$ & $\begin{array}{l}\text { Contains deposits of the Pulau Ayer Chawan } \\
\text { Formation }\end{array}$ \\
\hline BH1A9 & $\begin{array}{l}35556.18 \\
5925.54\end{array}$ & None & $\begin{array}{l}\text { Contains deposits of the Pulau Ayer Chawan } \\
\text { Formation }\end{array}$ \\
\hline BH1A1 & $\begin{array}{l}21459.02 \\
6770.81\end{array}$ & Tuas Formation & Contains deposits of the Tuas Formation \\
\hline
\end{tabular}




\section{Highlights}

- A new, ICS-compliant Paleozoic to Cenozoic lithostratigraphy for Singapore is proposed, which comprises 3 groups, 13 formations, 3 members

- Two new groups are proposed: the Jurong Group and Sentosa Group, the former correlatable with strata of the Semantan Formation of the Central Belt in Peninsular Malaysia

- The Jurong and Sentosa group strata were deformed during the Late Triassic-Early Jurassic orogenic event

- Mesozoic sedimentary rocks of Singapore record deposition in the Semantan forearc basin and the Tembeling transcurrent basin

- Deposition occurred in environments that range from deep marine to terrestrial, forming complex sedimentary bedrock geology in Singapore 
Graphical abstract
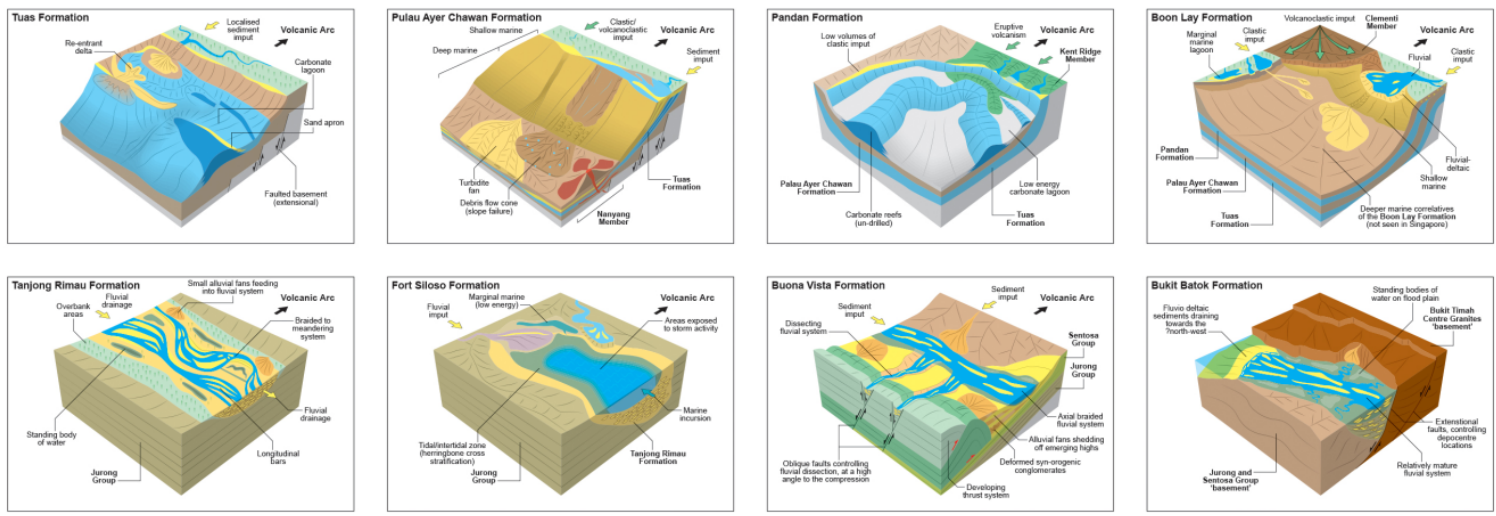